\title{
EL MAESTRO GUILLERMO BERAUD (VILLA DE RAFFARD C. 1700-REALEJO BAJO, 1752). NUEVAS APORTACIONES SOBRE SU VIDA Y OBRA
}

\author{
Germán F. Rodríguez Cabrera* \\ Miembro del Instituto de Estudios Canarios
}

\section{RESUMEN}

Este artículo pretende aportar nuevos datos sobre la vida y obra del francés Guillermo Beraud, establecido en Tenerife desde 1725. Elaborar una aproximación a su catálogo de obras en base al estudio documental y comparativo de las mismas. Lo genuino de su arte, el modo de trabajo y composición, la destreza que muestra con las herramientas permite identificar su mano en una serie de obras existentes o ya desaparecidas. Autor establecido en Los Realejos, lugar en el que desarrolló parte de su obra, ha permanecido poco estudiado en las últimas décadas. Su producción supuso la renovación estética de la plástica barroca insular. Palabras clave: Guillermo Beraud, Realejos, retablista, Barroco.

\section{MASTER GUILLERMO BERAUD (VILLA DE RAFFARD C. 1700 - REALEJO BAJO, 1752) NEW CONTRIBUTION ABOUT HIS LIFE AND WORK}

\section{Abstract}

This article intends to contribute new data about the life and work of the french Guillermo Beraud, established in Tenerife since 1725, and to elaborate an approach to his works catalog, based on the documental and comparative study of his works. The genuineness of his art, his way of working and composition, the skill that shows with the tools, allow us to identify his hand in a series of existent works or others already disappeared. Author established in Los Realejos, place where he developed part of his work, has remained little studied in the last decades. His production supposed the esthetic renovation of the insular baroque plastic. KeYwords: Guillermo Beraud, Realejos, altarpiece artist, baroque. 
En el presente artículo, pretendo profundizar sobre la obra y estética de un autor, Guillermo Beraud, del que poco se ha dicho desde los ańos ochenta del pasado siglo. La aparición de nuevas fuentes documentales ha permitido el adscribir nuevas obras, con certeza, lo que me ha permitido estudiar y relacionar otras obras existentes en la Isla. La relectura de otras fuentes, como su testamento, ha facilitado profundizar sobre su entorno familiar, en Francia y en Tenerife. El estudio de los padrinos de bautizo de sus hijos también nos ha acercado a sus relaciones sociales, cercanía a personajes de importancia para la sociedad de su momento, trazar un escueto mapa de los lugares donde habitó y relacionarlo con obras conservadas de su mano. La obra del maestro Guillermo Beraud, rica en matices, su destreza con la herramienta, con unos modos de trabajo que se identifican y unos diseños que aparecen en varias de sus obras, retablos principalmente, permite trazar un catálogo de su producción. Gran parte de sus obras, como otros muchos autores, permanecen catalogadas como anónimas. El estudio de la obra de arte es la principal herramienta de un historiador del arte, las fuentes completan, aportan luz, nos sacan de dudas, pero el estudio de las obras debe ser fundamental. Un apartado por el que se debe profundizar y tener a Beraud en cuenta es el campo de la escultura de mediados del setecientos. Tenido como maestro escultor en los ańos cuarenta de su siglo, en este trabajo le atribuyo varias esculturas como salidas de sus manos. La disciplina, su práctica, poco difiere de las capacidades que muestra y debe tener para el diseño de elaboradas tallas de amplios volúmenes, poco usuales en la plástica de la Isla. Maestro minucioso, de trabajados acabados, de cierta simplicidad en diseño de las estructuras, pero con características diferenciadas, que se completaban con ricas y en algunos casos minuciosas labores de tallas.

La realidad de la historia del arte en las Islas es dispar. Si por un lado los estudios en el campo de la pintura, la escultura o las artes suntuarias han avanzado; por el contrario, la realidad en otras materias, como la retablística o las labores de carpintería, no ha tenido la misma contestación. Este panorama, unido a las desafortunadas intervenciones, sobre edificios y sus bienes materiales asociados, han propiciado la desaparición de muchos de los elementos de estudio. La mera concepción como un simple objeto decorativo a propiciado un mayor desdén aún. Desde el primer trabajo de ámbito comunitario de Alfonso Trujillo, y el de Margarita Rodríguez sobre los principales autores de principios del s. xvin en Tenerife, poco se ha avanzado en el conocimiento de la retablística insular del setecientos ${ }^{1}$. El resto de

* Licenciado en Historia del Arte.

1 Trujillo Afonso, Alfonso (1977): Retablo barroco en Canarias, Las Palmas de Gran Canaria. Rodríguez GonzÁlez, Margarita (1986): Los maestros retablistas de principios del siglo XVIII en Tenerife, Coloquios Canarias América. Las Palmas de Gran Canaria. Más recientemente Lorenzo Lima, Juan Alejandro: Retablo y discurso estético en Canarias a finales de la época Moderna. Notas para un estudio contextual. Revista Vegueta, Las Palmas de Gran Canaria, 2017. En el cual se aborda la problemática de las nuevas disposiciones de la Ilustración en esta materia en las Islas durante la segunda mitad del s. XVIII. 
la información con la que contamos se ha ido publicando de manera tangencial en trabajos sobre templos, cofradías u otras instituciones religiosas.

Los retablos, arquitecturas lignarias, han ornamentado los templos isleńos desde de las aportaciones llegadas desde el norte de Europa hasta la actualidad. Levantados por manos formadas fuera de las Islas, en la escuela sevillana del seiscientos o por maestros locales, que recreaban, plasman las pautas y modas arquitectónicas llegadas de manos de la tratadística o las estampas. Modelos compositivos que, en parte, se perpetuán en el setecientos, pero con interesantes aportaciones en las labores de talla que los diferencian y personifican. Con la introducción del estípite como parte fundamental de la composición, la retablística local de la segunda mitad del s. XVIII evoluciona hacia formas más simples, descargadas de talla, pero sí rematadas con los pinceles de destacados pintores del siglo. La implantación de las formas neoclásicas, emanadas de las reformas ilustradas, no parece que pudiera acabar con la tradición barroca, que sobrevivió en el oficio y en muchas partes de las Islas, llegando su práctica y conocimiento hasta la actualidad.

En este trabajo intentaré ahondar sobre la figura del maestro Guillermo Beraud (villa de Raffard, c. 1710-Realejo Bajo, 1752), llegado a Tenerife en 1725. Partiendo de las piezas seguras de su mano y proponiendo nuevas adscripciones al mismo, de obras que han pasado desapercibidas o han desaparecido. El estudio de su entorno familiar, de sus estancias en la Isla y residencia en Realejo Bajo para contextualizar al personaje. Desde los primeros estudios donde se confundía su persona con la del también maestro de armar José de San Guillermo (Gran Canaria, 17331790), se ha ido clarificando su catálogo de obras. Desde un inicio se le venía atribuyendo la autoría de piezas muy singulares de las labores de carpintería en Tenerife. Sobre algunas de ellas se ha ido aportando luz, nuevas propuestas, en los últimos años dando nuevos nombres para la historia del arte insular. A la mano de «el Brujito» Juan Rodríguez Bermejo (...1709-1757) y sus hijos, Andrés y José, se le atribuye, ahora, el afamado púlpito de la parroquia matriz de la Concepción de La Laguna, levantado entre 1717 y $1727^{2}$. Al maestro lagunero, igualmente, se le adscriben la magnífica sillería de coro y facistol concluido en la década de los veinte o el retablo del Niño Jesús, originalmente en el trascoro, ahora en la capilla de las Ánimas, levantado entre 1720 y $1727^{3}$. Perdiendo así la atribución planteada a la mano de Beraud, pues las diferencias compositivas, elementos ornamentales de la talla y la cronológica así lo refutan. Quedan otras piezas, donde su mano se aprecia, pero que me generan dudas, como es el caso de la rica capilla de Carta en la parroquia matriz de capital tinerfeña. En 2007, Francisco Javier Herrera García suma al listado de las obras del maestro francés el retablo de la Santa Bárbara Mártir en la parroquia de

2 Santana Rodríguez Lorenzo (2003): El púlpito de los Brujitos, La Prensa-El Día, 18 de enero.

3 Lorenzo Lima, Juan Alejandro (2016): Una fábrica construida y reconstruida durante el siglo XVIII. Reformas, proyectos y arquitecto de la parroquia, en La Laguna y su parroquia matriz. Estudios sobre la iglesia de la Concepción. Instituto de Estudios Canarios, Ayuntamiento de La Laguna. La Laguna. 
Santiago Apóstol de Los Realejos. La correspondencia del patrocinador, el beneficiado y comisario del Santo Oficio Marcelo Fernández Vasconcelos (Realejo Alto, + 1769) con su agente en Sevilla, Pedro Massieu Vandale y Monteverde (La Palma, 1719-Sevilla, 1755), aporta las fechas de la obra y la autoría a Guillermo Beraud, quien lo levantó entre 1751 y $1752^{4}$. Otros, desde el siglo XIX, se dan como obra segura de su mano, como es el caso del retablo de Valois en el Puerto de la Cruz. Con este panorama, considero oportuna la revisión del catálogo de obras del francés afincado en Los Realejos en el primer cuarto del setecientos; de ir disipando esa nube que parece ocultar todo lo concerniente con su figura. Bien por rutina o falta de atención, muchas de sus obras han permanecido olvidadas o ignoradas por la historiografía. Sus retablos y tronos procesionales han permanecido en un segundo plano, relegados a simples muebles decorativos. No se ha apreciado la importancia que tienen para entender los gustos estéticos del setecientos.

Guillermo Beraud nació hacia 1710 en la villa de Raffard, en el Reino de Francia, como así se plasma en el acta de bautizo de su primer hijo, Domingo Agustín, el 13 de junio de 17345. Otros documentos lo sitúan en Burdeos y no en Bayona, como se venía afirmando ${ }^{6}$. Recientemente se ha publicado su partida de matrimonio donde lo sitúa como natural de Berat, anotación que creemos más fruto de una errata del beneficiado a la hora de interpretar el francés. En su testamento, solo se puede leer «el reino de Francia», pues la carcoma ha acabado con el resto de la línea. Era hijo del matrimonio formado por Leonardo Beraud y Margarita de San Ramón; pasó, posiblemente, parte de su juventud en el país galo, donde aprendería el oficio. De su entorno familiar sabemos que tenía otro hermano llamado Juan Beraud, que residía en el reino natal, con quien compartía bienes heredados de sus padres ${ }^{8}$. Llega a la Isla en 1725 asentándose en Realejo Bajo, lugar donde transcurren gran parte de sus años de vida, salvo los años que reside en La Laguna y Santa Cruz de Tenerife (1743-1745). Murió el 9 de noviembre de 1752, con 42 años, por causa de encontrarse "gravemente accidentado, esperando la muerte, como cosa tan natural a toda criatura...». Su cuerpo fue amortajado con el hábito franciscano «de la Seráfica Orden.... y y enterrado en la parroquia de Ntra. Sra. de la Concepción, posiblemente

${ }^{4}$ Herrera García, Francisco J. (2009): «Patrocinio artístico, gusto y devoción en Canarias durante el siglo XvirI. Algunos encargos escultóricos al taller de Duque Cornejo», Estudios de Historia del Arte, tomo II. Universidad de Sevilla, Sevilla, pp. 199-222.

${ }^{5}$ Archivo Histórico Diocesano de Tenerife, en adelante: AHDT. Fondo Parroquia de Ntra. Sra. de la Concepción. Realejo Bajo, Fondo Asociado, libro, n. ${ }^{\circ}$ 6, f. 118 v.

${ }^{6}$ Margarita Rodríguez González lo sitúa nacido en Bayona, pero en el testamento el deterioro solo permite leer que nació en el Reino de Francia. En su partida de defunción se le cita como nacido en Burdeos. Agradezco a Miguel Ángel Pérez Padilla este último dato.

7 Machado, José Luis (2019): Parroquia de la Concepción del Realejo Bajo. Libros de matrimonios de los años 1583-1799. Amazon, p. 489. La población de Berat es más distante que ninguna otra de Burdeos y Bayona. En cambio, la villa de Raffard es una pequeña población cercana a Burdeos.

${ }^{8}$ Archivo Histórico Provincial de Santa Cruz de Tenerife, en adelante: AHPT. PN. 3629. f. 472 .

9 AHPT. PN. 3629. f. 472, v. 
en una de las tumbas que poseía la familia Aguiar, como veremos más adelante. El resto de su testamento se lo dedica a sus hijos y a la última obra que tenía en taller, la cual ha permanecido sin identificar hasta ahora. Las causas de su llegada al Realejo Bajo se desconocen, podría haber estado motivado por las obras que se desarrollaban en el interior de su templo parroquial, que acababa de sufrir su tercera ampliación $^{10}$, o en algunos de los conventos que se alzaban en el lugar. Otra posibilidad, para su llegada y establecimiento en Tenerife, podría ser un alto en el camino de América, como otros muchos, y al encontrar un espacio de trabajo, decidieron permanecer en la Isla. Sirve como ejemplo habitual el caso del escultor andaluz Martín de Andújar, quien arribó a la Isla un siglo antes, creando un círculo de colaboradores antes de su partida hacia el Nuevo Mundo. Menos sabemos de otras figuras como el escultor andaluz Gabriel de la Mata, al que encontramos trabajando en el valle de La Orotava a finales del seiscientos. El caso de Guillermo Beraud parece no ser así, pues a su llegada, transcurridos ocho años, toma por esposa a la hija del escribano del lugar Josefa Juana de Aguiar y Chaves. Hija de Juan Carlos de los Santos Aguiar y Eufemia Fernández de Chaves, con quien se casa en la parroquia de la Concepción en $1733^{11}$. De ese matrimonio se desprende la solvencia y crédito que entre la sociedad se labró en menos de una década. Su casamiento y establecimiento en la Isla, le da la estabilidad necesaria para engendrar al menos siete hijos y ver crecer a cinco de ellos. Nueva generación que se inicia con Domingo Agustín en 1734, fraile dominico ${ }^{12}$, el que Viera y Clavijo destacó como una de las mentes más clarividentes de su tiempo, María Margarita, en 1735, de la que desciende Cándido Fernández-Veraud ${ }^{13}$. En 1737, nace el que parece ser el continuador del ofi-

${ }^{10}$ Camacho y Pérez-Galdós, Guillermo (1983): Iglesias de la Concepción y Santiago Apóstol, Comisión de Cultura, Ayuntamiento de Los Realejos.

${ }^{11}$ Rodríguez GonzÁlez, Margarita: opus cit.

12 El propio Viera y Clavijo lo menta entre los personajes más destacados por su intelecto de su tiempo en su Historia de Canarias. Viera lo elogia en los siguientes términos: «Dominicano, natural del Realejo de Abajo en Tenerife y lector de filosofía de los estudios del convento de San Benito de La Orotava. Aplicado desde muy niño a la lengua latina y aún a la griega, en que hizo algunos progresos, por lo que lo llamaron "El Griego" en su lugar, era ya mediano filósofo, cuando tomó el habito de Santo Domingo y cambió el nombre de Domingo, que antes tenía, por el de Agustín, año de 1768. Conságrese después de religioso con mayor ardor a todo género de estudios, especialmente a los del gusto de nuestro siglo. Obtuvo la cátedra de artes en su convento y procuró por la primera vez amenizar la sequedad del curso escolástico con una lógica más verdadera y una física más sensata. Todavía era estudiante, cuando hizo por si solo la inoculación de las viruelas en unos hermanitos suyos con gran felicidad. Sus ejercicios para la oposición a la cátedra fueron sobre el sistema copernicano, y su primer acto de conclusiones públicas, sobre el peso y la elasticidad del aire. La contradicción de los necios y la viveza de la su imaginación en un temperamento hipocondriaco le trastornaron la razón. Arrojase de una ventana y dijeron los que lo ridiculizaban sus estudios "que había querido pesar el aire y girar con la tierra". Como tenía talentos, amor al trabajo, a la humanidad, a la historia crítica y a la buena filosofía, su desgracia lo fue también del país».

${ }^{13}$ Fue alcalde del Realejo de Abajo, héroe de la defensa de Santa Cruz contra Nelson, además de autor de un importante trabajo sobre genealogía realejera que permanece inédito. 
cio paterno, Laureano Veraud ${ }^{14}$, el autor del retablo de la ermita de Las Angustias en Icod de los Vinos, tratado con posterioridad a 1757, por el fundador Marcos de Torres $^{15}$. En 1740 nace su hija Josefa, posiblemente la fallecida un año después en La Laguna. Tres ańos después (1743), estante en Santa Cruz de Tenerife la familia, nace José Guillermo, que falleció al año siguiente. Cayetano fue su último vástago, que tomó el hábito de la orden dominica como su hermano mayor.

La familia gozaba de una resuelta posición económica y social. Su esposa desempeñaba el rentable oficio de maestra sedera, importante industria que tanta presencia tuvo en el lugar ${ }^{16}$. A ello se deben sumar los diversos encargos que recibe el taller. Su trabajo como maestro de la carpintería de lo blanco y los cargos en la milicia, sabemos que llegó al cargo de ayudante, la cercanía a los que detentaban los cargos en la misma y lo novedoso de su arte le permitieron una interesante clientela. Relaciones sociales que se plasman en sus actos familiares. El estudio de las partidas de bautismo de sus hijos en Los Realejos permite apreciar los estrechos vínculos con diversos clérigos del lugar, como Pedro Martín de Chaves, Laureano Romay y Sepúlveda o el beneficiado de la Concepción José Álvarez Ferrer, que le garantizarían muchos de sus encargos eclesiásticos. También se relación con civiles, con vecinos del lugar como Pedro Pérez Vento o el administrador de la Hacienda de La Gorvorana Agustín García de Bustamante, padrino de su primer hijo. Las propiedades que su esposa, Josefa Juana de Aguilar y Chaves, poseía en ambos Realejos permitían compensar las rentas familiares. Tierras y casas situadas en ambos Realejos, dedicadas al cultivo de la malvasía. Ubicadas en el Realejo Bajo, «en el Canto de la Calle» o en el Realejo Alto en Zamora o El Lomito. En su testamento, Josefa Juana de Aguiar beneficia a su hija María Margarita «por razones de sus buenos servicios, amor y voluntad que le tengo» legándole «una casa vieja que está contigua a esta de mi morada "además de los telares" y otros y una mesa de oficio de sedero...». Lo que confirma la continuación a este floreciente negocio, que entraría en crisis a lo largo del s. $\mathrm{XIX}^{\mathrm{I7}}$. La vivienda familiar la habían heredado de su padres, el escribano De los Santos Aguiar, y era compartida la misma con su hermana de la siguiente manera: «La cuarta parte de la casa de mi morada que es la mitad de la media por tocante de dicho mi padre, que por causa del heredar de Andrea Barbara, mi hermana, únicos herederos de los dichos mis dichos padres ${ }^{18}$. Vivienda que situamos en el centro

${ }^{14}$ El apellido Beraud es usado por Guillermo con B y por algunos de sus hijos con V. En el caso de los nietos de su hija María Margarita, aparece siempre con V.

${ }^{15}$ Lorenzo Lima, Juan Alejandro (2014): «Arte, mármol y comercio en Canarias durante el siglo XviII. Otras pilas bautismales y benditeras de origen andaluz». Atrio. Revista de Historia del Arte, ${ }^{\circ}{ }^{\circ} 20$, Sevilla.

16 La seda y su presencia en el lugar es un apartado de la historia local, totalmente olvidado. De la importancia de la misma y su transcendencia, trabajo desde hace tiempo.

${ }_{17}$ AHPT. PN. 3633, f. 76.

18 AHPT. PN. 3633, f. 75. 


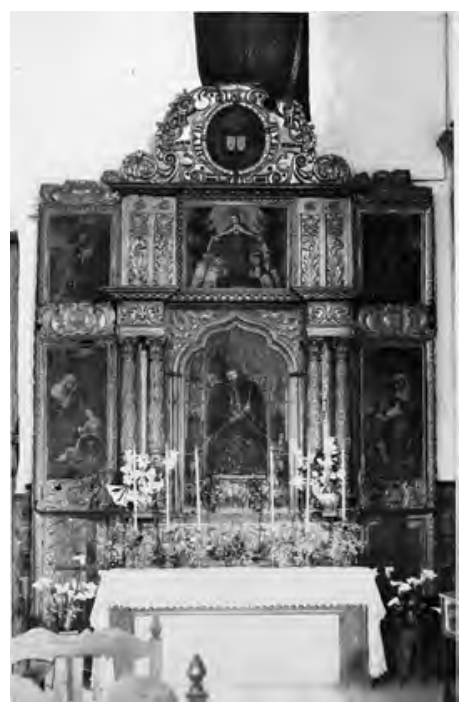

Foto 1. Retablo de Ntra. Sra. del Carmen. Parroquia de Ntra. Sra. de la Concepción, desaparecido en el incedio de 1978. Fondo Miguel Tarquis.

Biblioteca general y de Humanidades, ULL.

urbano del Realejo Bajo, la que años después ocupara su nieto Cándido FernándezVeraud en la calle de la Acequia, que aún se conserva en pie $^{19}$.

La esposa del maestro Beraud, Josefa Juana de Aguiar, le sobrevive hasta diciembre de 1759. Muere a los 50 ańos, el 26 de diciembre, recibiendo sepultura en la parroquia de Ntra. Sra. de la Concepción ${ }^{20}$. En su testamento, además de reconocer a sus hijos, y repartir las propiedades entre ellos, nombra como albaceas a Domingo, en ese tiempo clérigo de menores, y a Laureano. A su muerte, pide que su cuerpo sea amortajado con el hábito de la Orden de Santo Domingo de Guzmán «o la ropa sea de religioso o religiosa, como sea de dicha Orden». Ello hace suponer la cercanía que tenía con los mismos. Esta relación podría ser la causa de que dos de sus hijos encauzaran su carrera eclesiástica en las filas de los Predicadores, que no poseían convento en el lugar. De la sepultura de su cuerpo, pide que sea depositado "en sepulcro propio que tengo en la capellanía de la Iglesia parroquial del lugar». Capellanía que identificamos con la fundada por el clérigo Salvador de Aguiar en 1670, asociado al culto de la Virgen del Carmen en el templo de La Concepción $^{21}$. La religiosidad familiar se manifiesta, igualmente, en su pertenencia a

19 Sobre la misma preparo un trabajo, donde la identifico y analizo.

20 Debo este dato a la amabilidad de Miguel Ángel Pérez Padilla.

${ }^{21}$ Mesa Martín, José María (2013): «Turris Eburnea. Nuestra Señora del Carmen en Los Realejos: su culto entre los siglos XVII-XIX» en AA. VV.: Vitis Florigela. La Virgen del Carmen de Los Realejos. Emblema de fe, arte e historia, Los Realejos. 
diversas cofradías del lugar. Su hija Margarita aparece, junto a sus hijos, en las listas de hermanos de la centenaria confraternidad del Santísimo Rosario de la parroquial del Realejo Bajo ${ }^{22}$ (foto 1).

La llegada de la dinastía de los Borbones al trono español a principios del setecientos propiciaría la relajación de las tenciones entre ambos reinos y la entrada de franceses que se establecieron en diversos territorios del Imperio. En Los Realejos, hasta donde hemos localizado, se asentaron varios de ellos, tras la llegada de Beraud, que bien pudiera ser uno de los primeros establecidos. Entre la documentación que hemos consultado, localizamos a Marcos Achard, natural de Molmenor, que contrajo matrimonio con María Yanes Acosta en 1817, y a Juan Dupret, de Sant Maló, el cual casó con Mónica González en el mismo año ${ }^{23}$. Familias que desarrollaron su actividad en el lugar, en oficios como la pirotecnia, como el accidentado Vicente Achan ${ }^{24}$. Si bien estos casos descritos debemos relacionarlos con los presos galos llegados a las Islas durante la Guerra de la Independencia y que tras el fin de la contienda, decidieron permanecer en ellas. Paradoja que hace al caso de Beraud más singular aún. A la comunidad francesa, se sumaría en el setecientos, ya presente con anterioridad, los italianos, con apellidos en Los Realejos como Caputti, Margalli o Jacomini ${ }^{25}$.

De la formación artística de Guillermo Beraud, por ahora nada sabemos, pero debió de transcurrir en el medio francés, en el entorno paterno. En ese plano profundiza Herrera García dando los nombres del francés Jean le Pautre y los conocimientos en el uso de los balaustres, podrían relacionarse con las propuestas del arquitecto galo A.Ch. Daviler. Sus obras, presentes en tratados y estampas, dejan ver su influencia en las creaciones de Beraud. Tratados, estampas o apuntes que hubieron de formar parte del equipaje de nuestro maestro. La llegada a las Islas de las formas transalpinas que circulaban impresas en planchas abiertas en Francia, Alemania o Italia propiciaría un enriquecimiento y renovación del panorama insular, base fundamental para su obra.

La llegada de Beraud y las nuevas formulas aplicadas a la madera debió de significar un revulsivo, un nuevo empuje, por dejar atrás las formas del seiscientos. Nuevos enfoques que, en manos virtuosas, actualizaron el panorama ornamental de Tenerife. Guillermo Beraud junto a la labor desarrollada por la saga de «los brujitos» y otros maestros de lo blanco, que aún permanecen en la sombra, dieron un giro a

${ }^{22}$ AHDT. Fondo Parroquia de Ntra. Sra. de la Concepción. Realejo Bajo, Fondo Asociado, libro ${ }^{\circ}{ }^{\circ} 6$.

${ }^{23}$ AHDT. Fondo Parroquia de Ntra. Sra. de la Concepción. Realejo Bajo, legajo n. ${ }^{\circ} 21$.

${ }^{24}$ AHDT. Fondo Parroquia de Ntra. Sra. de la Concepción. Realejo Bajo, Libro 40 de defunciones. El 12 de mayo de 1847, se enterraba el cuerpo de Marcial Achan, de 51 años, como causa de "una explosión de pólvora en su casa». Natural de Molmenor, era hijo de Vicente Achan, natural del mismo lugar, y de Ana María Goré, que lo era de Viela.

${ }^{25}$ AHDT. Fondo Parroquia de Ntra. Sra. de la Concepción. Realejo Bajo, Libro segundo de matrimonios. En 1742 contrae matrimonio Nicolás Jacomini y Margalli, hijo del capitán de caballo Luis Jacomini y Margalli y María Martínez de Herrera, con Bárbara Alzola Acevedo y Padilla. 
la situación. La obra del maestro Guillermo debió de provocar un impacto en una disciplina muy dependiente de los modelos de tradición renacentista y manierista. Con estructuras definidas por la proporcionalidad, la distribución de los espacios en calles y cuerpos, modelos puestos en boga y difusión por la amplia obra de Antonio Álvarez (ya activo en Tenerife en 1669) que con variaciones, y grandes capacidades en las labores de talla, se mantenían como base o esquema compositivo general para todo buen retablo que se preciara. Inician la renovación las grandes obras de autores contemporáneos a Guillermo Beraud como son Juan González de Castro Illada (La Laguna, c. 1640-1717), Antonio Francisco de Orta (La Laguna, 1654-1717) ${ }^{26}$ y Antonio Estévez, creadores de desarrolladas tallas vegetales, de las columnas salomónicas frente a las estriadas del seiscientos y tallas de menor volumen. Ellos fueron los autores de los grandiosos retablos de la actual catedral lagunera (1718) y el retablo mayor de la iglesia del convento de monjas clarisas de la misma ciudad ${ }^{27}$. El estípite logró gran dinamización y evolución en las manos del maestro Guillermo. Dotando, como bien apunta Herrera García, de un aire renovado y cosmopolita a sus retablos, frente al resto del panorama insular.

De la fortuna crítica de que gozó en vida el maestro francés hablan las obras contratadas y los lugares donde se levantaron. Pieza clave son los patrocinadores de los mismos, clero regular, secular y lo más granado de los comerciantes insulares. Las cartas del beneficiado Marcelo Fernández Vasconcelos lo definen como «un maestro francés de los primeros de esta Ysla», hablando de su trabajo ante Pedro Massieu, palmero residente en Sevilla que se encargó del envío de la escultura de santa Bárbara Mártir. Considerado, igualmente, como «maestro» aparece referenciado en las cuentas de la Cofradía de la Misericordia de Realejo Bajo. Tras su muerte, su fama, asociada a su obra, transcendió como bien recoge Agustín Álvarez Rixo (1796-1883), quien tratando del retablo de Valois del convento de monjas catalinas del Puerto de la Cruz, deja en sus escritos la siguiente cita: «... obra prima, ejecutado con bastante gusto en su estilo por maestro Guillermo Veraud». Como vemos, su estilo causaba admiración entre gran parte de los habitantes de la Isla. No tuvo igual suerte de crítica el retablo de la Misericordia (1735-1746), que para la cofradía homónima realizó el maestro en la parroquia del Realejo de Abajo. En palabras del beneficiado Pedro Prospero González Acevedo, casi un siglo después, (1820), quien entre las reformas que pretendía realizar en el templo parroquial pretendía «... quitar de las naves tantos malos retablos todo con acuerdo y licencia del superior ${ }^{28}$. Esta es, posiblemente, la causa de la desaparición del retablo, de nueva planta, que realizó Beraud para la parroquia donde reposa su cuerpo. Modificaciones promovi-

${ }^{26}$ Rodríguez Morales, Carlos (2016): Todo es de plata. Las alhajas del Cristo de La Laguna, Ayuntamiento de La Laguna. En el presente trabajo, su autor perfila los márgenes cronológicos de estos dos autores.

27 Rodríguez González, Margarita: opus cit.

${ }^{28}$ Hernández González, Manuel Jesús (2004): «La Inmaculada Concepción y la Villa de Los Realejos. Espacios y Culto», en Inmaculata. 1854-2004, catálogo de la exposición homónima celebrada entre el 22 de noviembre y el 6 de diciembre de 2004. Los Realejos. 


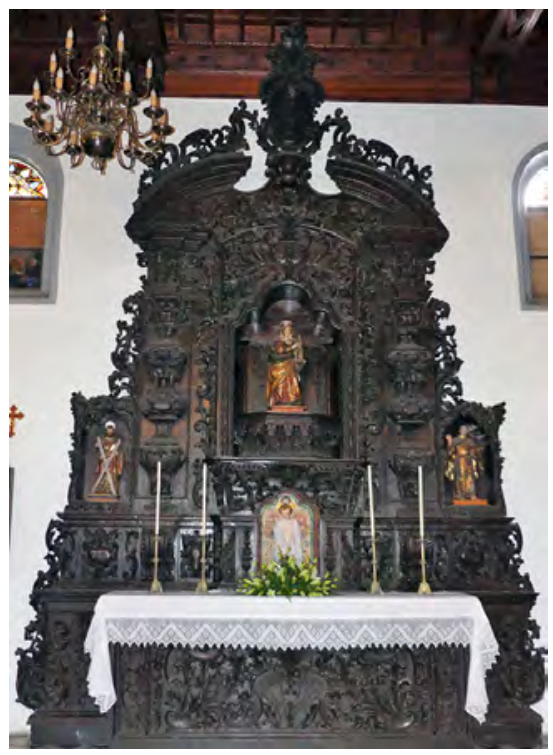

Foto 2. Retablo de Santa Bárbara. Parroquia de Santiago Apóstol. Los Realejos.

das por el renovador beneficiado, que pretendía introducir los gustos clasicistas en una fecha ya bastante tardía. El retablo que se perdió en el incendio de 1978 nada tenía que ver con las formas de Beraud y sí con un clasicismo carente de gracia. Otra faceta a valorar en el maestro Guillermo es la definición por parte de José Antonio de Vera, quien, en 1746, lo llama maestro escultor ${ }^{29}$. Lo que nos hace plantearnos que a la destreza con la gubia para el desarrollo volumétrico de formas vegetales, textiles y arquitectónicas, debería poseer la misma capacidad para plasmar las formas humanas. Idea no descabellada, a mi entender, y de la que dejan buena constancia las figuras angelicales que parecen presentes en sus obras. La consideración de Beraud como escultor sería de interés para ir completando el discurso que sobre la escultura de principios del s. XVIII se realizaba en Tenerife (foto 2).

$\mathrm{Si}$ analizamos su obra encontramos características comunes en todas ellas. Sus retablos se caracterizan por plantas rectangulares, que si bien responden al habitual esquema de tres calles, las mismas son recortadas en planta, con amplias hornacinas centrales y arcos mixtilíneos. Espacios divididos por estípites o columnas salomónicas de laborioso tallado, medallones ornamentados que rellenan los espacios, guirnaldas y guías vegetales remarcan las líneas compositivas. Las molduras poseen amplia presencia, de diferentes cortes, dando paso a un segundo cuerpo o

29 Rodríguez GonzÁlez, Margarita: opus cit. 
remate. Segundos cuerpos, centrados por lienzos o emblemas tallados que permiten articular una composición, alejada de las formas arquitectónicas. La talla y las molduras, sobre los planos de cada cuerpo, son las que toman protagonismo a la hora de componer. Tallas vegetales con formas de flores, tallos de laurel, mirtos, conchas y medallones que centran las composiciones, hojarascas y roleos que rompen las líneas arquitectónicas. Se completan con amplias ménsulas, junto con molduras y tallas, que rompen lo plano de cada calle. El uso de líneas compositivas para diseñar plantas con recortes, con pequeñas entradas, las cornisas con más desarrollo en las partes superiores de los soportes provocan sutiles juegos con la luz. A ello se suman los pabellones que remarcan algunas de sus hornacinas o los arcos mixtilíneos y conopiales para abrir hornacinas, que aparecen ampliamente rematados por composiciones ricamente talladas, centradas, generalmente, por un medallón. El uso de guardamalletas, colgaduras, cordones y borlas, recursos de aparato, opulentos, de tramoya que enriquecen sus composiciones. Guillermo Beraud logra en sus composiciones unos retablos efectistas, plenamente barrocos, que a la luz natural y la de las velas lograrán un amplio efecto de relieve, que, recorrido por la luz, plasma una nueva estética, un barroco pleno, más continental.

Festones, guirnaldas, cintas ornadas en sus extremos de roleos y tallos, detalles vegetales, que dotan a sus composiciones de gran belleza y plasticidad. Beraud combina en sus obras, elementos que plasman soluciones textiles de su tiempo. Pabellones de los que penden ricas guardamalletas y pesados cortinajes, que se sujetan por cordones y borlas. Las guardamalletas de tres lóbulos hacen que las construcciones lignarias se dotan de ese efecto teatral, ricamente ornamentado, que en unión de la policromía o de las calidades de las maderas usadas dan un aspecto suntuoso a sus creaciones. En el caso de las piezas procesionales, aparecen subdivididas por pilares, que con formas vegetales y amplias volutas dotan de ritmo a las composiciones. Como soportes constructivos usa los estípites, de formas geométricas sobre los que aplica las tallas o con formas más redondeadas, donde la talla se realiza de forma directa, como sucede en los retablos de Valois y santa Bárbara Mártir, respectivamente. En otros casos, introduce columnas salomónicas en los extremos, con ricas tallas florales, en la vuelta más expuesta caso del altar del Tránsito de las catalinas laguneras. La destreza que demuestra con la gubia hace de la obra de Beraud una producción diferenciada entre el resto de sus contemporáneos. Similar destreza se aprecia igualmente en labores como escultor, pues ángeles y otras figuraciones poseen una soltura que nada envidia a otros artistas. Todo ello nos presenta a un autor diestro en el dibujo y el modelado, con un sentido de lo teatral de equilibrado gusto. Un discurso renovador y solvente en el Tenerife de la primera mitad del setecientos.

\section{RETABLOS, NUEVAS PROPUESTAS}

En los inicios de la década de los treinta del setecientos se idea el encargo de un nuevo retablo para la reconstruida iglesia de San Ana de Garachico tras los efectos del volcán de 1706. El retablo que ahora se encuentra en la cabecera del convento de las monjas concepcionistas. Documentado por González Regalado en 
fechas cercanas a $1730^{30}$, fue trasladado como causa de los mandatos del obispo Antonio Tavira para la reforma jansenista de la cabecera de Santa Ana en torno a 1794. Su desmontaje propició que se volviera a levantar en la cabecera del convento de las monjas de Santa Clara del mismo pueblo. Tras las leyes de desamortización y derribo del mismo, el interesante retablo fue rescatado de la destrucción y colocado en su ubicación actual ${ }^{31}$. Descrito así por Alfonso Trujillo:

De un solo cuerpo y ático, se levanta sobre un alto banco, con puertas de paso a la sacristía en los lados [...]. Los estípites son de dos tipos: a los extremos y para la calle central, con un segundo cuerpo abalaustrado, mientras que del lado de las entrecalles las dos porciones se invierten [...] con los que se produce una distorsión asimétrica de clar o efecto barroco. [...]. El ático corresponde al tipo de pabellón, que aquí no pende de corona, sino de una cupulillas de base poligonal ornamentada con borlas y rematada con una cornisa muy movida [...] sobre las calles laterales dos bellos medallones de marco muy ondulante...32.

Como bien describe, presenta los característicos estípites que dividen las tres calles, que en un orden gigante, suben hasta la línea de cornisas. Se remata el segundo cuerpo con pabellón y cortinas recogidas en los extremos. A ambos lados, dos marcos, ahora ocupados por san Pedro y san Cristóbal, salidos de los pinceles de Ubaldo Bordanova (Madrid, 1866-Santa Cruz de La Palma, 1909). Incorporaciones posteriores a su construcción son el manifestador y las puertas de acceso a la sacristía. En todo lo demás, descrito por Trujillo Rodríguez, creía apreciar detalles de la mano del maestro Guillermo, pero lo temprano de la fecha, la magnitud de la obra y detalles del trabajo de talla me hacían dudar. A ello se sumaba su juventud por esas fechas y la importancia del encargo. Tras varias indagaciones documentales, hemos podido recabar información acerca del encargo del mismo y la autoría, confirmando mis sospechas. En 1731 el beneficiado de la reconstruida parroquial de Santa Ana, Manuel de Acosta Perera, eleva junto a Pedro Bautista Delgado, mayordomo de la Hermandad del Santísimo Sacramento, un documento a sus superiores informando sobre la realidad de la capilla mayor del templo. La misma estaba presidida por la imagen de Nuestra Señora de la Luz y el Crucificado ${ }^{33}$, estando el Santísimo depositado en la capilla de los marqueses de La Florida. El encargo se había realizado al maestro Francisco Antonio Ubiche, con el cual habían pactado la obra en un diseńo previo, por un precio de dos mil setecientos veinte reales, a la que se

30 González Regalado, Pascual (1958): «Evocaciones históricas de Garachico. Pasado y presente de la parroquia Matriz de Santa Ana», La Tarde, Santa Cruz de Tenerife, 24 de julio.

${ }^{31}$ Acosta García, Carlos (1994): Apuntes generales sobre la historia de Garachico, Aula de Cultura de Tenerife.

32 Trujillo Rodríguez, Alfonso: opus cit., pp. 148-149.

33 Ambas imágenes corresponden con la mariana que se conserva en el templo de los Ángeles (antiguo convento franciscano), olvidada por la historiografía y los devotos. El Cristo al que hace referencia el documento es el tallado por Martín de Andújar para el retablo destruido por el volcán, y que a día de hoy sigue presidiendo el altar mayor de la parroquial de Santa Ana. 


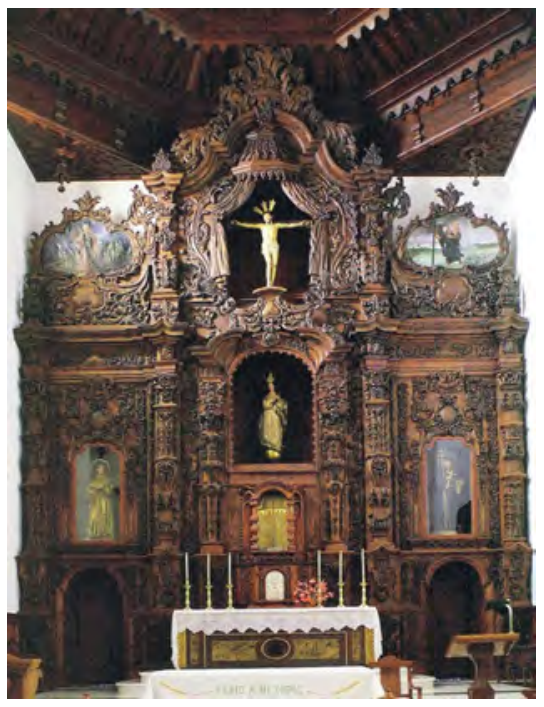

Foto 3. Francisco Antonio Ubiche. Antiguo retablo mayor de la parroquia de Santa Ana, ahora en la iglesia del convento de monjas concepcionistas. Garachico.

sumaba la madera de viñátigo, que ya poseía la parroquia en su poder, que debía servir "para la fachada y relieves...». La misma se financiaría con los propios fondos de la hermandad sacramental, la fábrica parroquial y el legado testamentario de doña Lucía de Castro Navarro ${ }^{34}$. La presencia de este nuevo maestro de lo blanco, aparte de poder completar la información sobre el tema, nos permite plantearnos la atribución de otros retablos a su mano. La poca documentación con que contamos sobre su figura no nos avala para poder trazar un eje vital del mismo. Pero me hace pensar en la influencia o vínculo que pudo tener con Guillermo Beraud (foto 3).

De entre los patrocinadores que depositan su confianza en Beraud destaca el comerciante portuense Nicolás Bernardo Valois (Puerto de la Cruz, 1706-1741). Burgués, de origen irlandés, quien le encarga en fecha cercana a la de su muerte el retablo conocido por su apellido para el convento de monjas catalinas del Puerto de la Cruz. Trasladado posteriormente a la capilla de las Ánimas de la iglesia parroquial del lugar. Fue un regalo a una de las monjas del convento, con la que le unía mucho afecto. La obra estaba dedicada a santa Catalina de Alejandría y las hornacinas laterales ocupadas por los santos patronos o de pila del donante (santos Bernardo y Nicolás). Con una estructura simple, de un solo cuerpo, dividido en tres calles por estípites de recortadas formas, destaca la hornacina central, que rematada por arco mixtilíneo, abre a una hornacina ochavada y nervada con pilares que, remarcan su planta. Este tipo de hornacina parece ser característico de Beraud,

${ }^{34}$ AHDT. Fondo Diocesano. Legajo 1714, documento 12. 
como se aprecia en algunas de las intervenciones que realiza. El encargo del rico comerciante, que desempeñó diversos cargos en la milicia, establece un discurso de unión entre la religiosidad y el lugar de origen, apareciendo rematado por el lema y las armas de Irlanda. Nos habla de igual manera de la clientela del maestro Beraud, pues Valois era uno de los más refinados comerciantes de los que tenemos constancia, prueba de ello es el retrato que de él se conserva. En él aparece de tres cuartos, cubierto por amplio manto de color azul y peluca a la francesa ${ }^{35}$. En el mismo templo conventual se alzaba el púlpito, obra considera del maestro francés y desaparecida en el incendio de $1925^{36}$. De cómo llegó el maestro Guillermo a conseguir este importante encargo nos puede ayudar la partida de bautismo de su hijo mayor. El 13 de junio de 1743 recibe las aguas bautismales Domingo Agustín José Nicolás Antonio de la Ascensión, el futuro fray Agustín de Beraud, primer hijo documentado del francés y de Josefa Juana de Aguiar. En su partida aparece como padrino de bautismo Agustín García de Bustamante, vecino del Puerto de la Cruz ${ }^{37}$. Don Agustín había llegado a Tenerife como personal de confianza de los adelantados de Canarias para hacerse cargo de la administración de sus cuantiosos asuntos entre 1706-1709. Tras este servicio al conde de Torralba pasa a residir, de manera permanente, en la Isla, donde logra el cargo de administrador del mayorazgo de la Gorvorana entre 1724-1746 $6^{38}$. La necesidad de trato con la naciente burguesía para comercialización de los productos de las tierras a su cargo lo llevaría a tener contacto con Bernardo Valois, unos de los más importantes comerciantes de la Isla. A ello añado que, si bien la Gorvorana poseía en la casona de la hacienda de su nombre su residencia principal, pasó a tener bajo su administración casa propia levantada en el centro de la vecina urbe portuaria (foto 4).

La factura del retablo de Valois permite establecer relaciones entre las características del francés con otros retablos existentes en Tenerife. A la composición habitual, donde estípites de diversa solución dividen las calles, se suma la existencia de amplias volutas que rematan los laterales del banco, que sirven de soporte a los cuerpos superiores, recurso compositivo que resulta una constante en su producción. De entre los trabajos tradicionalmente asociados a su mano, se encuentra el retablo del Tránsito de Nuestra Seńora, ahora en la iglesia del convento de monjas catalinas de La Laguna. Si bien la producción asociada a Beraud en la Ciudad de los Adelantados ha sido revisada y adscrita a las gubias de Los Brujitos, el reta-

35 Conservado en colección particular de sus descendientes, la obra, copiada por Álvarez Rixo en su archivo, la consideramos salida de los pinceles de José Rodríguez de la Oliva (1695-1777), uno de los mejores retratistas de su momento. Igual opinión plasmó Carmen Fraga en el trabajo sobre los irlandeses en el catalogo Sacra Memoria. Arte religioso en el Puerto de la Cruz, 2001.

${ }^{36}$ Calero Ruiz, Clementina y Hernández Díaz, Patricio (1982): «El convento de Nuestra Señora de las Nieves, San Juan Bautista y Santo Tomás de Aquino. Puerto de la Cruz (Tenerife)», $V$ Coloquios Canarias-América. Gran Canaria.

37 AHDT. Fondo Parroquia de Ntra. Sra. de la Concepción. Realejo Bajo, libro 6, fol. 118 vt.

38 Sobre su figura ha trabajado en 2006, Arvelo García, Adolfo: Propietarios absentistas y administradores emprendedores. Una mirada a la sociedad canaria del s. XVIII, desde la correspondencia privada de Agustín García Bustamante. 


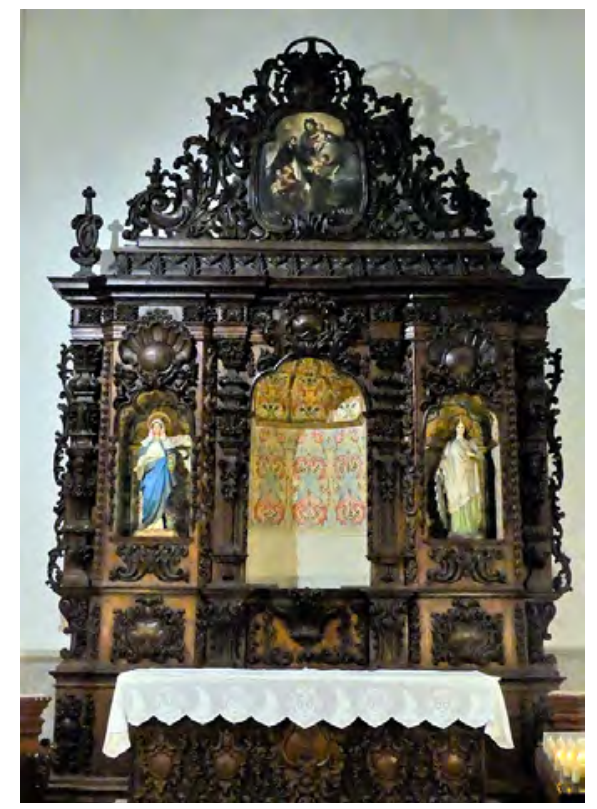

Foto 4. Retablo de Valois. Parroquia de Ntra. Sra. de la Peña de Francia. Puerto de la Cruz.

blo del Tránsito no ha sido puesto en cuestión y creo que debe permanecer asociado en su producción, pues presenta soluciones propias del francés. Encargado por Santiago Álvarez de Abreu y su esposa Francisca Valdés, personajes claves del patrocinio artístico en La Laguna de su tiempo. En 1724 logran la sesión de una antigua celda en el claustro agustino para crear una capilla y destinarla al culto del Tránsito de Nuestra Señora. Si bien la imagen titular la realizó fray Miguel Lorenzo en torno a 1703, la devoción toma verdadero auge con la fundación de los Álvarez de Abreu, que la vinculan en el mayorazgo redactado en 1735. Este retablo de pabellón, que se abre para mostrar la imagen titular remarcado por dos estípites que sirven para dividir en tres el cuerpo que compone la obra. En las calles laterales, dos hornacinas de caprichosas formas acogen las figuras de los santos titulares de sus patronos. Hornacinas rematadas por veneras de estilizado trazo, remarcadas por tallos vegetales. El frontal del mismo presenta soluciones compositivas similares a las dadas para el del retablo de Valois y que aprecio igualmente en el retablo mayor de los agustinos de La Orotava. Las soluciones dadas en las tallas vegetales y los estípites que se sitúan a ambos lados del nicho son comunes a la obra de nuestro autor. Todo el conjunto se completa con gran cantidad de angelotes, abren las cortinas y sostienen la hornacina central como pequeños atlantes. Ángeles y santos patronos que me hacen ahondar en la faceta escultórica del francés; ya el portuense José Antonio de Vera lo definió como maestro escultor en 1743 . Esta apreciación y la presencia de figuraciones humanas en otras de sus producciones nos llevan a plantear la necesidad de 


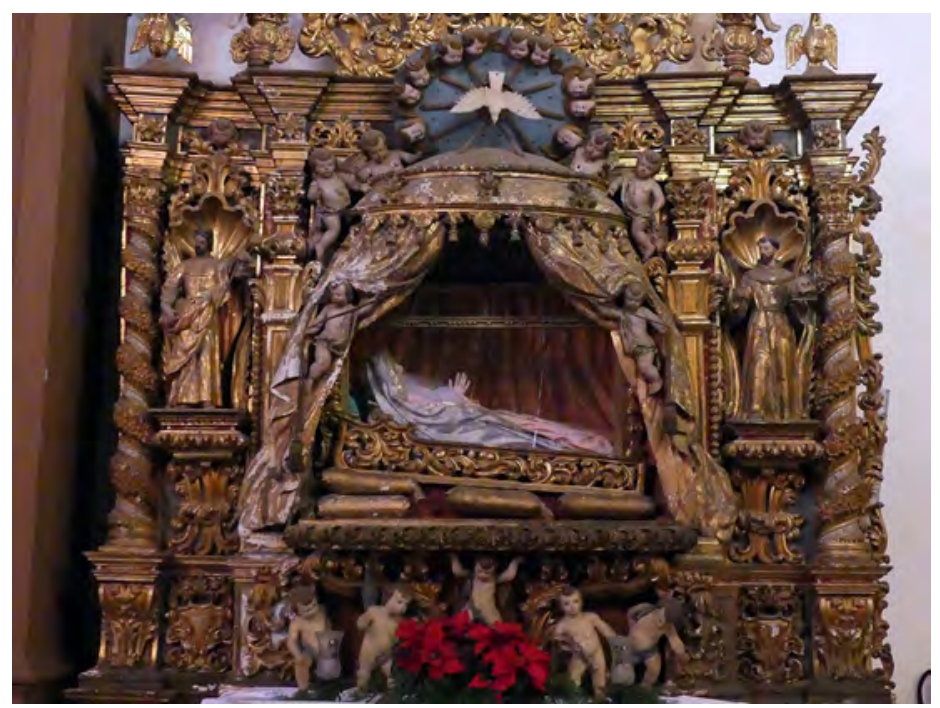

Foto 5. Retablo de Ntra. Sra. del Tránsito. Convento de Sta. Catalina de Siena. La Laguna.

tenerlo en cuenta en el campo de la escultura insular del setecientos ${ }^{39}$. De la relación del maestro Guillermo Beraud con la Ciudad de los Adelantados se ha documentado su residencia en la misma, al menos durante el año de 1741. El 4 de mayo de 1741, se entierra en la iglesia de la Concepción «una niña de Guillermo Beraud, vecino, junto a la Iglesia» ${ }^{40}$. Lo que demuestra la residencia durante al menos más de un año, en los entornos del templo parroquial lagunero, como para ser considerado como vecino (foto 5).

Desde enero de 1743 hasta julio de 1745 aparece establecido en la calle de El Castillo en Santa Cruz de Tenerife. En esa floreciente población, Beraud bautiza a su hijo José Guillermo en la parroquia de Nuestra Señora de La Concepción. Un año más tarde es el lugar de entierro del pequeño. Su llegada a la urbe puede estar motivada por las obras que se estaban realizando en varios de los principales edificios religiosos. En ella, se ha asociado a sus manos la realización de la capilla de Carta en la antesacristía de la parroquia matriz. Ya puesta en duda por la profesora Margarita Rodríguez en los años ochenta. Postura a la que me sumo, con cierta reserva,

39 En este sentido su obra presenta características comunes en el planteamiento del volumen de los cuerpos, lo blando de las carnes y los tratamientos de las cabelleras y barbas. Además, las esculturas de los ángeles parecen ser un recurso para sus composiciones, como veremos en su obra final. Debemos sumar a los ángeles, las esculturas de Santiago y san Francisco de Asís del retablo lagunero y otras conservadas en diversos puntos de la Isla aún en estudio.

40 AHDT Fondo parroquia de Ntra. Sra. de la Concepción. La Laguna, libro 6 entierros, fol. 80 vt. Debo este dato a la amabilidad de Daniel García Pulido. Debe de tratarse de su hija Josefa. 
pues, a pesar de ser un tema poco trabajado, en el estudio de la obra se aprecia la mano de varios autores. Recientemente Francisco J. Herrera ha propuesto la atribución a su mano del retablo, ahora, del Corazón de Jesús de la Concepción santacrucera, vínculo que no comparto, como tampoco la realizada para el retablo del Calvario de la parroquia de San Juan Bautista de la villa de La Orotava ${ }^{41}$.

En cambio si aprecio su mano en el retablo de San José en la iglesia de San Francisco de Santa Cruz de Tenerife, antiguo templo del convento franciscano de San Pedro Alcántara. Siguiendo la información facilitada por Inchaurbe Aldape, la obra se levantó en una capilla dedicada al santo, en el claustro, entre 1730 y 1733, por encargo del capitán Pedro Castellano ${ }^{42}$. Las consecuencias de la desamortización en este edificio no han sido calibradas y habría que valorar si este retablo, ahora de San José, en origen no lo fue, entre otras razones pues, como documenta Inchaurbe, la capilla y altar de San José que se alzó por Castellano fue en el claustro principal y no en las naves del templo, donde se ubica la obra trabajada ${ }^{43}$. El estudio del mismo nos permite apreciar las características propias de Beraud, a pesar del grave deterioro que presenta, repintes y algunas modificaciones. Si bien es cierto que para las fechas dadas podría ser una obra temprana, encuentro en su análisis semejanzas compositivas y recursos ornamentales presentes en el retablo de Valois y el Tránsito, realizados en los años cuarenta. Columnas de profundas gargantas, ornadas de guirnaldas de flores, medallones con hojas de acanto en el entablamento, como sucede en el retablo de los agustinos de La Orotava y Valois. Volutas de amplio desarrollo en los extremos de la base del primer cuerpo que sirven de sostén a guirnaldas que rematan los extremos. El trabajo en las hojas de acanto, de los marcos de formas vegetales de los lienzos superiores están presentes en el retablo de santa Bárbara. Similar resolución encuentro en los angelotes alados de los frisos, con los rostros de los ángeles del retablo lagunero. Todo ello me hace pensar en una obra salida de sus manos, levantada durante el tiempo de estancia en la capital de la Isla (foto 6).

El retablo mayor del antiguo convento agustino de la villa de La Orotava es otra obra que atribuyo a sus gubias. Desapercibido para la historiográfica insular, solo es Alfonso Trujillo quien lo trata en su magna obra. Descrita como «de dos cuerpos, se destina el principal a hornacinas, y en el superior a pequeños lienzos de marco elíptico. Los estípites son notorios por su elevado canon... Los motivos decorativos son de técnica muy aristada, como trabajada con formón destacándose la del frontal con cenefa que enmarca una zona central en la que siete espejos de acuartelada disposición llevan letras talladas que recomponen el saludo angélico: AVE GRA PNA». Es el mismo autor quien establece su cronología en los años

41 Herrera García, Francisco J.: opus cit., p. 201.

42 Inchaurbe Aldape, Diego (1966): Noticias de los provinciales franciscanos de Canarias, IEC. La Laguna.

${ }_{43}$ Tampoco contribuye a filiar la obra con la creación del capitán Castellano, cuando en los tres lienzos que componen el segundo cuerpo aparecen representados san Juan de Dios, san Lorenzo en el lienzo central y san Juan Bautista, salidos de tres manos diferentes, como se desprende de su estudio. 


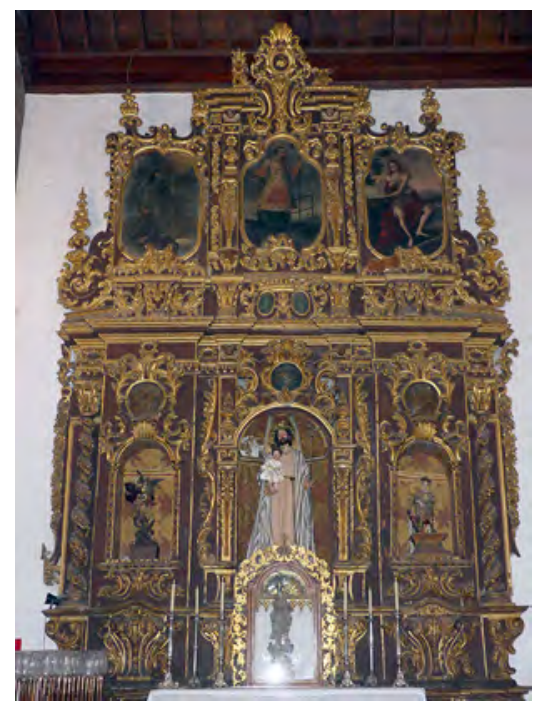

Foto 6. Actual retablo de San José. Parroquia de San Francisco. Santa Cruz de Tenerife.

cuarenta del setecientos. Presenta, salvo el tamaño y el orden gigante de su primer cuerpo, solución poco usual en las Islas y grandes similitudes con los retablos de Beraud. Compositivamente posee el mismo esquema de el retablo de Valois, donde ambos cuerpos son dominados por estípites que dividen las calles, que se resuelven de manera pareada entre los centrales y los extremos, haciendo juego entre ambos. El diseño de los mismos se compone de estructuras geométricas, lo que simplifica el trabajo desde un punto de vista técnico, permitiendo un mejor ensamblaje y ganar mayor tamaño. Estructuras a las que se aplican, posteriormente, las tallas completando el relieve. Volumen de los estípites aparece remarcado en la línea de cornisas, rompiendo la horizontalidad con quiebros angulados en sus uniones. El retablo presenta soluciones en la talla similares a las de Valois, en el remate, a modo de capitel, en los pilares de los extremos, aparece un diseño similar de laso vegetal, igual al usado en los remates laterales del retablo portuense. El segundo cuerpo está dominado por tres lienzos en cada una de sus calles ${ }^{44}$. En torno a los marcos se organi-

${ }^{44}$ El lienzo central está dedicado a la advocación mariana de El Socorro, que versiona al lienzo que se conserva en la ermita de su nombre en Tegueste, tan vinculada con la orden agustina. De la misma mano que el lienzo mariano, un anónimo pintor de mediados del setecientos, es el lienzo que representa al fundador de la orden dominica, que junto al san Francisco de Paula, este presenta soluciones muy próximas a Cristóbal Hernández de Quintana, completan el cuerpo superior. Discurso, con la presencia de estos santos, que plantea la hermandad entre dominicos, ya presentes en la villa, y principales perjudicados por la llegada de los agustinos, y franciscanos, que representados 


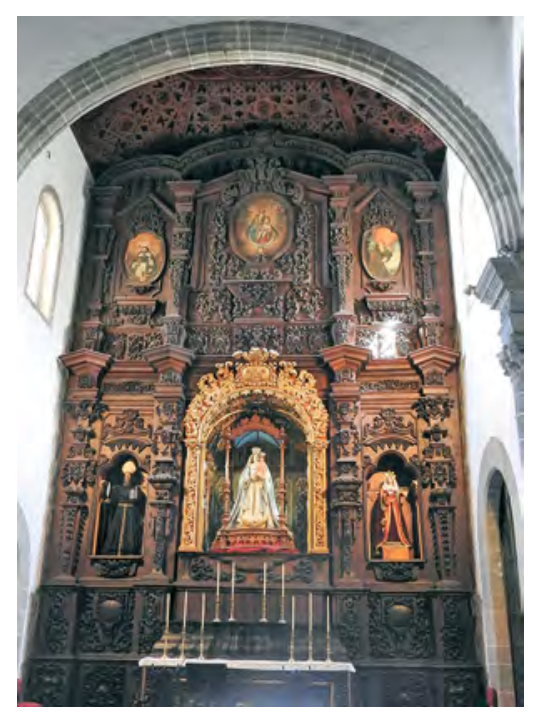

Foto 7. Retablo mayor. Exconvento de Ntra. Sra. de Gracia. La Orotava.

zan una serie de cornisas y tallas que componen y resuelven los pańos; jugando con los volúmenes y la luz de las ventanas laterales. Las tallas de este segundo cuerpo y las calles laterales del primero presentan soluciones, repertorios, detalles, grandes medallones orlados de guirnaldas vegetales que se repiten y remiten a otros retablos ya citados del maestro francés. Sobre las cornisas del segundo cuerpo remata todo el conjunto una guardamalleta, de rica talla, con borlas en sus extremos, que plasma un concepto de teatralidad. El retablo es una arquitectura barroca para sorprender al devoto, que es totalmente novedosa a estas escalas en la plástica insular (foto 7).

Debemos hacer referencias a dos intervenciones en dos retablos, ya existentes, en las dos parroquias de Los Realejos. En la del Apóstol Santiago, aparte del retablo ya citado de santa Bárbara Mártir, debemos citar el sagrario presente en el retablo de la Cofradía de la Sangre y Misericordia de Cristo. Pese a la simple composición estructural es rico en las labores de talla. La puerta presidida por el Cordero Eucarístico, situado sobre barroca mesa, es iluminado por un rompimiento de Gloria presidido por el Triangulo Divino u Ojo de la Providencia. Los laterales se resuelven con estípites tallados muy similares a los presentes en la hornacina inferior del retablo vecino de santa Bárbara. El interior del sagrario, aunque inacabado, no deja lugar a dudas de su vínculo con la obra de Beraud. Dos pilares simi-

por el santo de Paula, floreciente devoción en ese siglo, pretendían cicatrizar las heridas abiertas con la fundación de Santa María de Gracia. 


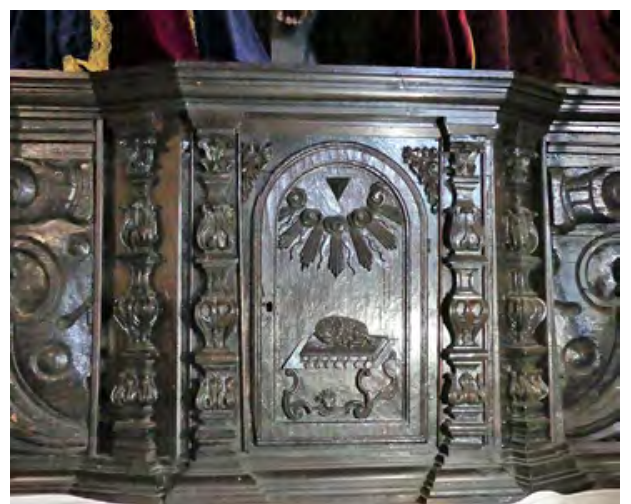

Foto 8. Sagrario, retablo de la Misericordia. Parroquia del Apostól Santiago. Los Realejos.

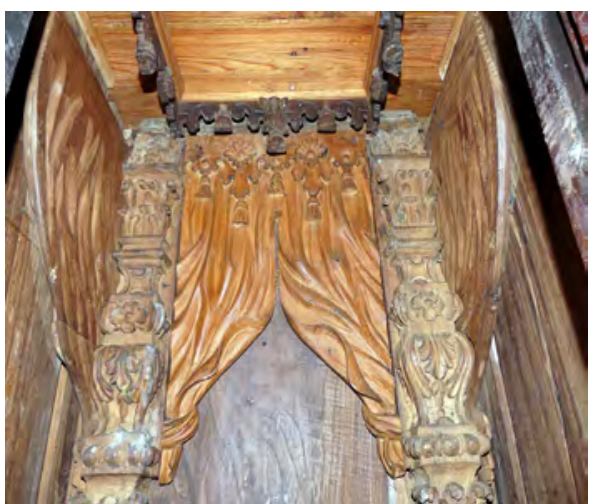

Foto 9. Detalle interior del sagrario, retablo de La Misericordia.

Parroquia del Apostól Santiago. Los Realejos.

lares en talla y diseño sostienen a ambos lados, en el fondo del sagrario, una guardamalleta, similar a la que cuelga de la peana de santa Bárbara y la urna del Santo Entierro, con flor central y borlas en los extremos. Tras de ella se abre una cortina, tallada, recogida a los lados, y otro cortinaje en los laterales del sagrario. El trabajo del interior de la caja, sin barniz y rematado en su totalidad, nos permite apreciar la destreza con las gubias por parte del maestro Guillermo. El estudio de las cuentas de la Cofradía de la Misericordia refleja varias anotaciones respecto a las mejoras de sus enseres. En 1747 se anota en los gastos de 22 reales por «composición de la mesa y otras menudencias» ${ }^{45}$ que debe aludir a la reforma de la mesa de altar y sagrario. En ese tiempo los cultos de la cofradía corrían a cargo de Marcelo Fernández de Vasconcelos, promotor del retablo de santa Bárbara. En los libros de la confraternidad no se anotan más intervenciones en el retablo y sí en las imágenes de la Magdalena, a la que se dota de ropas y peluca, o a la Dolorosa a la que se le compra nuevo manto y se mejoran sus andas. La no finalización del mismo podría corresponder a la falta de fondos o a la repentina muerte de Beraud. El otro ejemplo es el sagrario y frontal del desaparecido retablo del Rosario de la vecina parroquia de Ntra. Sra. del Rosario, del que hablaremos más adelante, una obra ya desaparecida desde 1978 (fotos 8 y 9). 


\section{ANDAS PROCESIONALES. LA MODERNIZACIÓN DE LAS FORMAS, LA LLEGADA DEL BARROCO PLENO}

Los postulados del Barroco, las tesis del Concilio de Trento, apostaban por la catequesis a la población. La persuasión a las gentes, que con difícil acceso a las letras, tenían depositadas en las procesiones una parte de sus creencias. Para las salidas a la calle había que dotar de unas andas, o parihuelas con varales, a las imágenes veneradas. Cortejos en los que participaban cofradías, hermandades, clero regular, secular y el resto de la población. El traslado de los cultos internos al exterior propició, y así lo hace aún, la creación de unos enseres o elementos propios para ello. De las primeras canastillas, parihuelas, andas o tronos poco conservamos, aunque a lo largo del s. XVII tuvieron amplio desarrollo. No es precisamente hasta el siglo siguiente cuando encontramos los primeros ejemplos conservados. En las Islas se produce un modelo, más o menos generalizado, de trono procesional fruto de la llegada de piezas o modelos foráneos y la evolución propia de manos de autores locales. La llegada de prácticas andaluzas como las andas de palios aún se conservan varios ejemplos, caso de las usadas por el conjunto de las lágrimas de san Pedro y la Soledad de la Portería del antiguo convento franciscano de Gran Canaria. En cambio otros han desaparecido como las usadas, con varas de madera dorada, de la Soledad que los Montiel entronizaron en su capilla del convento agustino de Icod de los Vinos en el s. $\mathrm{XVII}^{46}$. Este modelo de paso evolucionó, en Canarias, hacia las andas de baldaquino que se han perfilado como el modelo más genuino de las Islas ${ }^{47}$. A modo de templete de planta cuadrangular con cuatro columnas o pilares que sostienen una cubierta plana o nervada, rematada por carteles, y otros motivos zoomórficos o vegetales. Los primeros ejemplos conservados son del seiscientos, con gusto manierista, logran su máxima expresión en la siguiente centuria. Con alma de madera, forradas de planchas de plata repujada, cubiertas de pan de oro o plata, o policromadas. Piezas usadas, mayormente, por imágenes marianas, también lo son para santos como es el caso de san Benito Abad y san Roque en La Laguna o san Antonio Abad en La Matanza de Acentejo. Generalmente recubiertas de planchas de plata repujada que forran toda la estructura lignaria, muchas de ellas se realizaron de manera colectiva (cofradías o hermandades) o como patrocinios particulares. Pueden servir de ejemplo las realizadas para la imagen de Ntra. Sra. del

${ }^{46}$ Gómez Luis-Ravelo, Juan (2000): «De la historia de la Semana Santa de Icod. Acontecimientos piadosos de la primera mitad del siglo Xvir. Las huellas andaluzas y las expresiones barrocos». Revista de patrimonio histórico-religioso de Icod. Comisión de la Semana Santa, Icod de los Vinos.

${ }^{47} \mathrm{La}$ actualidad de estas aportaciones está mediatizada por la llegada de modismos andaluces, que si bien funcionan en su comunidad, con variables entre ellas, no parecen encajar en la realidad insular. Falta de aprecio, pero también de conocimiento, sobre un patrimonio asociado a las procesiones y altares de tradición barroca que ha sobrevivido al paso del tiempo y modas. Estos, los modelos insulares, son fruto de un proceso de decantación de fórmulas llegadas a esta sociedad de fronteras que a lo largo del setecientos definió unos modos propios, ahora infravalorados en beneficio de fórmulas ya descartadas siglos atrás. 
Carmen de Los Realejos, regaladas por el capitán Agustín de Torres y Chaves en la primera mitad del s. XVIII o las construidas por la cofradía de Ntra. Sra. del Rosario de la parroquia de la Concepción, del mismo lugar, en la década de los ochenta del s. XVII ${ }^{48}$. También existen ejemplos de baldaquinos cubiertos por cientos de hojas de pan de plata u oro, que logran diversos efectos bien por el bruñido o el uso de corlas y el dibujo signado sobre la preparación. De entre las más conocidas podríamos citar las usadas por el patrón de la cementeras, san Benito Abad, en La Laguna. En pan de plata las que llevan a la imagen de Ntra. Sra. de las Angustias en Icod de los Vinos, sufragadas por el indiano Marcos de Torres a mediados del s. XVIII. Similar solución presentan las usadas por la Virgen de los Reyes en Garachico con un diseño de la segunda mitad del siglo. De ese tipo de baldaquino, pero de dos pilares y dosel que cubre a la imagen titular, debemos citar las andas de san Vicente Mártir en Los Realejos, que sobre dos balaustres se sostiene el techo, cielo o dosel, rematado con carteles en sus frentes y jarrones en sus esquinas ${ }^{49}$. Cercano, aunque enriquecido con interesantes labores de talla, con menor amplitud en el dosel y con la espalda de la titular cubierta por una rica tela, es la que usa la imagen de las Angustias en Tazacorte, ambos ejemplos propios de la segunda mitad del s. XVIII. Las pinturas objeto de veneración también generaron un modelo de andas, para sus salidas procesionales, sobre varias plataformas se sitúa un sitial o dosel, donde se coloca la obra. Destacan las andas de Ntra. Sra. del Socorro en Tegueste ${ }^{50}$ o las de las de san Juan Evangelista de la parroquia matriz lagunera, ambas con ricas labores de plata repujada de talleres tinerfeños. Caso singular, ahora desunidas, son las de san Juan Bautista de la ermita de su nombre en Güímar, donde se portaba la tabla flamenca titular del templo desde el s. Xvi, ahora en la península ${ }^{51}$. Otros casos son las canastillas, bases o tronos, en los que se portan, descubiertas, imágenes de Cristo o santos. Entendiendo que desde las formas más simples, parihuelas, que se enriquecían con telas, piezas de platería, piezas para la iluminación y otros ornamentos como flores de talco y papel, que evolucionaron hacia estructuras más elaboradas como las conservadas a partir del s. XVIII. Durante esta centuria se plasma la influencia andaluza en este tipo de andas. Su influjo se deja ver en la canastilla que porta el paso de la Oración en el Huerto propiedad de la Orden Tercera de Santa Cruz de Tenerife. De planta rectangular y perfil de pecho de paloma, totalmente calado, en su superficie aparece recubierto por planchas de plata repujada, trabajo insular de

48 Sobre esta confraternidad preparo un trabajo desde hace tiempo. De las andas citadas, aún se conservan gran parte de ellas, reutilizadas en las actualmente usadas y en diversas piezas conservadas en dependencias parroquiales.

${ }^{49}$ Las que portan al patrón de Los Realejos en la actualidad no son las originales, son una recreación de las originales realizadas en los años noventa del pasado siglo. Las antiguas, conservadas en parte en la propia ermita, presentan soluciones de la policromía, sobre maderas recortadas y molduras, que recuerdan las maneras de pintor dieciochesco Cristóbal Afonso (1742-1797).

50 Pérez Morera, Jesús (2014): Alhajas de la Virgen del Socorro en Patrimonio religioso de la Villa de Tegueste, edición bajo la dirección de Carlos Rodríguez Morales, Ayuntamiento de Tegueste.

51 Debo tal información a la amabilidad de Javier Eloy Campos, en una reciente visita al lugar, donde entre otros temas resolvió mis dudas sobre este particular. 
la segunda mitad del setecientos. El trono del Nazareno de Santa Cruz de la Palma representa un raro caso, hasta donde sabemos, de los regalos llegados desde América. Enviado por Cristóbal Pérez Volcán (1725-1790) desde Cuba, sigue las pautas de un evolucionado barroco muy cercanas a las fórmulas cortesanas europeas. El conjunto se completa con cuatro angelotes, portadores de los instrumentos de la Pasión, de igual procedencia ${ }^{52}$. Este campo, el de las andas procesionales, con sus variables para imágenes de bulto o lienzos, es un campo a trabajar. Un espacio en el que llevo tiempo profundizando y del que hay mucho por investigar y reflexionar. Contando con el problema de que, al ser muchos de ellos piezas de uso, sufren las consecuencias del mismo, deterioros, pérdidas y alteraciones. Otros ejemplos han tenido peor suerte, ha desparecido o han sido desmembrados, total o parcialmente.

La vinculación del género con las labores de Guillermo Beraud se inicia en los trabajos para la parroquia de la Peńa de Francia del Puerto de la Cruz, por mediación de José Antonio de Vera. En 1746 se encontraba realizando el nuevo trono para el Gran Poder y la Virgen de la Peńa. Trabajo documentado por Margarita Rodríguez y que, hasta donde sabemos, no ha llegado hasta nuestros días. Las andas fueron sustituidas, por ser de pequeño tamaño, siendo vendidas en América como se desprende de los documentos de la cofradía mariana:

Se hace cargo de quatrocientos dos reales y medio mitad de ochocientos y cinco porque se vendieron unas Andas fabricadas por mitad para la imagen del Gran Poder de Dios y la sobre dicha Nuestra Señora de la Peña cuia venta se hizo para Caracas por mano de Thomas García de León con el motivo de no haber salido a proporción de dichas Insignias y la dicha enajenación se hizo en el año de $750^{53}$,

siendo sustituidas por otras salidas de la mano de José Tomás Pablo «el morenito» (+ Puerto de la Cruz, 1778). En cambio, para la patrona parroquial fueron iniciadas a platear unas nuevas en 1771 cuando se le entregan 200 reales a "Gabriel Hernández Ramírez por labor de plata de las Andas» trabajos de forrado en planchas de plata que parecen estar concluidos en 1775 como se desprende del ejercicio económico de la cofradía de Nuestra Señora de la Peña entre los años 1772-1775:

Por dos mil trescientos treinta y uno los reales que han importado las hechuras de las Andas, labor de plata así consta como de la suma de estrellas y algunos hierros para dichas andas... ${ }^{54}$.

52 Rodríguez-Lewis, J.J. (2005): Apuntes sobre la Semana Santa de Santa Cruz de La Palma, Más Canarias. Santa Cruz de la Palma.

53 AHDT. Parroquia de Ntra. Sra. de la Peña, Fondo Asociado, legajo no 1, s/f. Fueron sustituidas las del Gran Poder de Dios por otras diseñadas por el pintor José Tomás Pablo, igualmente desechadas en el s. xIx por las presentes, de gusto neoclásico. Las actuales reproducen una base y arranque de una columna de corte clásico.

${ }^{54}$ AHDT. Parroquia de Ntra. Sra. de la Peña, Fondo Asociado, legajo n. ${ }^{\circ} 1$. f1. 5. 
Como sabemos, el maestro Beraud vivía en el entorno de la parroquia del Realejo Bajo, edificio eclesiástico que con el florecimiento del seiscientos, consecuencia del negocio vitivinícola, permitió levantar un gran edificio de tres naves. La gestión de la misma se enfrentó en el siguiente siglo a un crecimiento más lento, dependiente de la productividad de la tierra y de los trabajos elaborados en los múltiples talleres sederos del lugar. La menor rentabilidad de las vides provocó que muchas de las mandas y funciones creadas décadas antes no pudieran tener continuación en el siglo siguiente. Un ejemplo de ello es lo sucedido con las funciones impuestas por el regidor y capitán Fernando Pardo del Castillo, quien en 1660 dota a la Cofradía de la Misericordia de imágenes para las procesiones de El Mandato y La Sangre, para la tarde y la noche de Jueves Santo ${ }^{55}$. La crisis generada por el desplome de los precios del vino y el desinterés de los herederos de Pardo del Castillo y Ana Machado, su mujer, propiciaron la venida a menos de los cultos. Si bien es cierto que la confraternidad de la Misericordia se hizo cargo del culto al Crucificado, no sucedió igual con el Cristo de la Humildad y Paciencia que presidía la procesión de la Sangre. Como se ha documentado, el abandono de los priostes de sus obligaciones favoreció la participación activa del resto del vecindario en el culto al Cristo de la Humildad. En 1730 la procesión no salió a pesar de las limosnas del pueblo; ante esta situación, la hermandad del Santísimo decide asumir la financiación de la misma y asociar sus gastos al hermano designado, anualmente, como hermano mayor. De esta manera se sumaba el cargo de prioste de la Sangre entre sus honores y obligaciones, dando más prestigio y preeminencia al nombramiento anual. En 1741, se documenta el cambio de denominación del Cristo de la Humildad y Paciencia y se registra el nombre del Ecce Homo. Es pues en torno a esta fecha cuando debemos documentar la intervención que atribuimos al maestro Beraud, el nuevo trono o andas procesionales del antiguo Cristo de la Sangre. Patrocinadas por uno de los hermanos mayores de ese año o posteriores, como encargo privado, no aparece recogido en la contabilidad de la hermandad. El libro de cuadrante comunal confirma esa idea: «... En el paso d Ecce Homo, Miércoles Santo por la mañana con sermón y demás que cuida el hermano Maior del Stmo. en esta parroquia $\aleph^{56}$. La renovación de la misma propicia un aumento de su devoción y recorrido de sus cortejos procesionales, los cuales hacen estación en cada uno de los conventos del lugar «... que va un año al convento de San Francisco y otro al del Señor San Agustín y monjas.... ${ }^{57}$ (foto 10).

La composición de las nuevas andas para el Cristo de la Sangre viene acompañada de la reconversión de la imagen en un Ecce Homo, llamado popularmente Señor de la Cañita, revistiendo con una túnica a la escultura del s. Xviı atribuida a

55 Mesa Martín, José María (2008): El esplendor de la Semana Santa del siglo XVII, en la Iglesia Parroquial de Nuestra Señora de la Concepción: La cofradía de la Misericordia, sus procesiones y otras dotaciones de Pasión, Programa de la Semana Santa, Ayuntamiento de Los Realejos.

56 AHDT: Fondo Parroquia de la Concepción, libro n. ${ }^{\circ}$ 55, s/f.

57 Idem. 


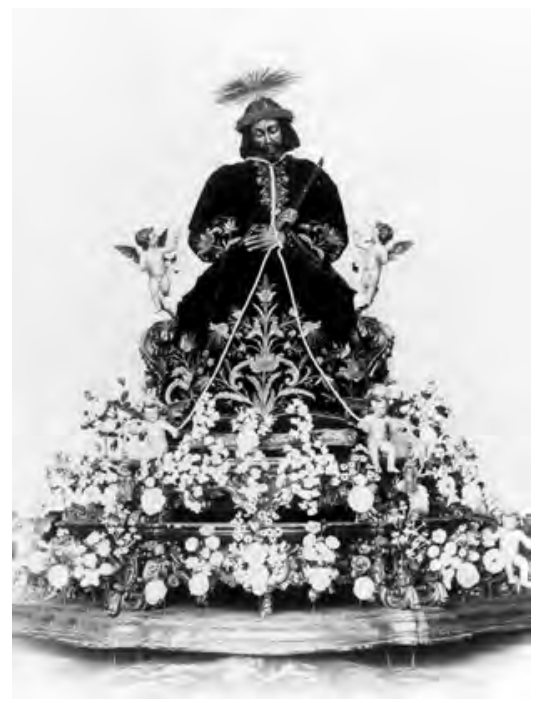

Foto 10. Andas del Ecce Homo. Anónima final del s. xix. Col. Particular. Los Realejos.

la mano de Alonso de la Raya ${ }^{58}$. Si bien la imagen se reaprovechó, las nuevas andas del Cristo responden a un nuevo modelo, plenamente del setecientos, completando la idea de renovación que se buscaba. De dos alturas, de planta sexagonal, sobre 16 pilares ricamente tallados con amplias volutas y tallos vegetales. Cada una de las plataformas aparece ricamente tallada, en sus frentes, centrados por medallones de marcos tallados por roleos y formas vegetales. La decoración del más amplio, primero de ellos, se enriquece por una guirnalda que recorre todo su frente. Sobre estas dos plataformas se coloca la imagen titular, sentada sobre un rico taburete que repite similares soluciones decorativas que soportan cuatro potentes patas labradas por tallos y volutas. Las andas descritas sobrevivieron al incendio de noviembre de 1978, que destruyó todo el interior del templo. En origen doradas, en la actualidad se encuentra oculto por, al menos, dos capas de repintes ${ }^{59}$. Las andas del Cristo del Realejo Bajo nos pueden servir para hacernos una idea del similar encargo rea-

${ }^{58}$ Así lo plantea José María Mesa en el artículo anteriormente citado. Propuesta que suscribo, pues el material fotográfico conservado permite un estudio razonable del mismo. De la pieza, desaparecida en el incendio de noviembre de 1978, se conserva la mano izquierda, ahora en colección particular.

59 A finales de los años noventa del pasado siglo, siendo párroco Juan Manuel Batista Núńez, quien las botó a la basura, no sin antes destrozar algunas partes del mismo y del antiguo trono del Señor Preso, obra de la segunda mitad del s. Xviır. Recogidos de la calle por los afamados carpinteros hermanos Hernández Siverio. Ellos propiciaron su reposición al uso tras su recomposición y adquisición una nueva imagen del Ecce Homo, salida de las gubias de Ezequiel de León. En este proceso participaron, al igual que en el s. XviII, muchos de los vecinos del lugar. 


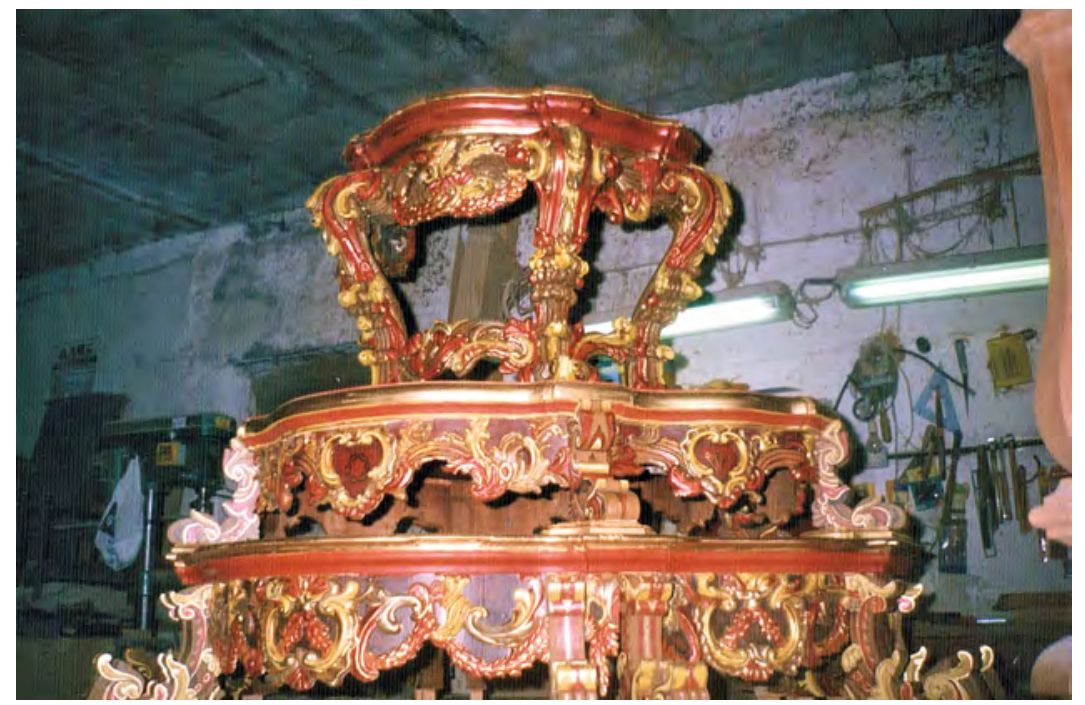

Foto 11. Andas del Ecce Homo. 1999. Parroquia de la Concepción. Los Realejos.

lizado en la misma década para el Gran Poder de Dios del Puerto de la Cruz. Presenta ciertas similitudes en diseño y composición el paso de Cristo Predicador en el convento de San Benito de La Orotava, con las soluciones de Beraud para el caso realejero. Ahora separados, su atribución a las manos del maestro galo me provoca muchas dudas, ante la escasez de datos y ciertas soluciones que aprecio en la obra que se alejan de los modos del maestro Guillermo ${ }^{60}$. Pero sí nos sirve de ejemplo de un nuevo gusto, de ricas tallas y dorados, que materializa en las décadas centrales del setecientos un pleno Barroco (foto 11).

Antes del citado incendio de 1978 la parroquia de la Concepción de Los Realejos conservaba una serie de retablos donde se apreciaba la mano de Guillermo Beraud. El antiguo retablo del Carmen acogía al Ecce Homo en el momento de su desaparición, desconociendo el momento de su colocación en el mismo. Si analizamos la obra lignaria su única hornacina era fruto de una intervención posterior, del setecientos, sobre un conjunto del siglo anterior. El retablo de Valois permite plantear comparativas entre otras piezas, donde la obra realejera presenta muchas similitudes. Desde el arco conopial con la agrupación de varios pilares que lo remarcan, la peana que elevaba a la escultura, similar a otras soluciones presentes en la peana del retablo de santa Bárbara de la parroquia de Santiago Apóstol o en las andas relicario de La Orotava. En su interior, la hornacina presenta similitudes donde su com-

${ }^{60}$ En la actualidad la silla y el Cristo que labrara Blas García en el s. Xvir se conservan en la parroquia de la Concepción y el trono, ahora usado por el Cristo de la Humildad y Paciencia, en el antiguo templo agustino de la misma población. Sería de agradecer la recomposición del conjunto. 
posición sigue el corte conopial inicial presentaba cinco lados, ricamente policromados. La reforma en el retablo, la colocación de la nueva hornacina se ejecutó antes de 1758, año en el que la Cofradía de Nuestra Señora del Carmen de la parroquia de la Concepción, titular del mismo, se descarga de «30 reales y siete octavos» pagos a Felipe Paiva (...1758...) para ayuda del dorado del nicho ${ }^{61}$. Este retablo era una fundación de la familia Aguiar, estirpe de la mujer de Guillermo Beraud, donde en su cercanía poseían tumbas propias. En una de ellas quería ser enterrada Juana Josefa de Aguiar y Chaves; y donde pienso podría estar enterrado nuestro artista.

La mano de Beraud se apreciaba de igual manera en la mesa del altar y sagrario del retablo de Nuestra Señora del Rosario. Si bien la obra fue realizada por Antonio Álvarez, como se desprende la documentación y el estudio de las fotografías conservadas. En cambio el sagrario y el frontal del altar corresponden a otras manos y época. Preparado para ser usado como manifestador, el sagrario estaba dotado de un husillo en su base, que permitía la elevación de la caja interior rematada por la cúpula. La puerta cóncava del sagrario sobre la cual resaltaba el símbolo eucarístico del «Pelícano alimentado a sus crías con su sangre» estaba tallada en barbusano. A sus lados se encontraban doce columnas salomónicas, vacías en su interior, ornamentadas por formas vegetales, que mostraban lo muy diestro de su autor con las gubias $^{62}$. Tradicionalmente y de manera oral se ha transmitido la intervención del francés Beraud en su realización, de igual manera se lo atribuye Guillermo Camacho en su monográfico sobre las parroquias realejeras ${ }^{63}$. A ello debemos sumar la relación de los Beraud, con su varias veces centenaria cofradía dando testimonio las listas de hermanos, donde su hija y sus nietos, los Fernández-Veraud aparecen con miembros de la misma ${ }^{64}$.

El maestro francés cita en sus últimas voluntades una sola obra de las salidas de su mano, aún en su taller. Dada a conocer por Margarita Rodríguez cuando acota la vida de Beraud, no ha sido identificada hasta el momento, cuestión que pretendemos solventar en esta ocasión. En su último documento, Guillermo Beraud, a pesar de encontrarse en grave estado de salud, cita su última creación casi concluida, declarando:

... a ver contratado con la Religiosa del convento de Santa Clara de La Orotava, con la Muy Rda Madre Dońa Isabel de Mesa, religiosa del dicho convento, unas

${ }^{61}$ Rodríguez GonzÁlez, Margarita (1986): La pintura en Canarias durante el s. XVIII, Cabildo Insular de Gran Canaria, Gran Canaria, p. 401.

${ }^{62}$ El incendio de 1978 nos privó del conjunto, retablo, tradicionalmente asociado a las manos de Beraud. Era la pieza de mobiliario más descrita de su interior por la bibliografía artística como de viajeros. En la actualidad, la capilla del Rosario muestra una réplica realizada siguiendo las pautas tradicionales de talla.

${ }^{63}$ Camacho Pérez-Galdós, Guillermo (1983): Las Iglesias de la Concepción y Santiago Apóstol. Comisión de Cultura, Ayuntamiento de Los Realejos.

${ }^{64}$ En los listados de cofrades de la misma, parecen inscritos en 1776 su hija María Margarita Beraud. En la misma lista parecen los hijos de esta Gregorio, Amaro, Cándido, Josefa María y Adriano Beraud. 
andas o custodia para el Corazón de Jesús, cuya obra la deje quasi vencida y para complemento del ajuste que hizo solamente le falta que recibir veinte y cinco pesos, con los cuales no duda que habiendo persona que sepa dirigir y finalizar dicha obra, tiene bastante para su perfección en cuya inteligencia y trabajo que en dicha obra tiene aplicado se halla a ver satisfecho la cantidad que así tiene satisfecho... ${ }^{65}$.

Como vemos da a conocer el nombre de la patrocinadora, el uso y lo satisfecho que se encuentra. El estudio de la obra de Beraud permite conocer las fórmulas compositivas y los recursos que se plasman en sus tallas, en sus creaciones. La pieza tratada, hasta el momento no se ha identificado, la reconozco en el llamado relicario procesional que se conserva entre los bienes de la Parroquia de Ntra. Sra. de la Concepción de La Orotava. La obra ha permanecido mal identificada y sin catalo$\operatorname{gar}^{66}$. Si bien es cierto que siempre se ha vinculado al convento de Santa Clara como su lugar de procedencia, no se ha definido el uso del mismo. Entre los muros del templo de monjas clarisas de San José se alzaba un altar dedicado al Sagrado Corazón de Jesús, del que era pieza principal la obra tratada. Descrita así recientemente por José Lorenzo Chinea Cáceres:

La estructura se articula sobre una basa circular con cornisas salientes en las que descansan sus ocho patas ovaladas decoradas con motivos vegetales. Estos elementos vuelven a aparecer encintados en el cuerpo central, sobre el que brota un gran ostensorio oval laureado y rocallas recortadas. El conjunto está rematado por una corona imperial con engastes fingidos y un pabellón con cortinaje de telas encoladas y pintadas al óleo, que descubren dos pequeños ángeles sedentes. Completaban el conjunto otros ocho ángeles policromados y dorados que se colocaban en las repisas de cada pata, hoy perdidos ${ }^{67}$.

Es la última referencia a una pieza a la que falta la descripción de su parte trasera, cuestión que ha sido imposible de resolver hasta el momento ${ }^{68}$. Tenida como un relicario procesional, de una reliquia no identificada ni superviviente a la caída del Antiguo Régimen ${ }^{69}$. En la actualidad solo usadas para las tramoyas levantadas como parte del Monumento del Jueves Santo. En la pasada Semana Santa, tras

${ }_{65}^{65}$ AHPT. PN. 3629.

${ }^{66}$ El último trabajo sobre el templo, sobre los bienes asociados a su museo El Tesoro tampoco aporta novedad alguna sobre el mismo.

${ }^{67}$ Chinea Cáceres, José Lorenzo (2017): «Mobiliario», en El Tesoro. Catálogo del Museo Sacro de la Parroquia de Ntra. Sra. de La Concepción de La Orotava, Gobierno de Canarias, pp. 161-181.

${ }^{68}$ A pesar de los intentos, este particular, como tomar sus medidas y poder estudiarla con detenimiento ha sido imposible. A modo de reflexión, y crítica, diría que de nada vale una instalación museográfica si esta se limita a ordenar en el espacio y no a catalogar, ni fichar al pie de cada obra y, sobre todo y más importante, facilitar el acceso a los investigadores. Lamentable realidad de lo que más parece un coto privado que una institución eclesiástica.

${ }_{69}$ Manuel Hernández González en su trabajo sobre los conventos de La Orotava cita algunas de las de mayor veneración. Destaca las «del queso de San Lorenzo» y las de «San Plácido y San Pío Mártires» de las que nada queda. 


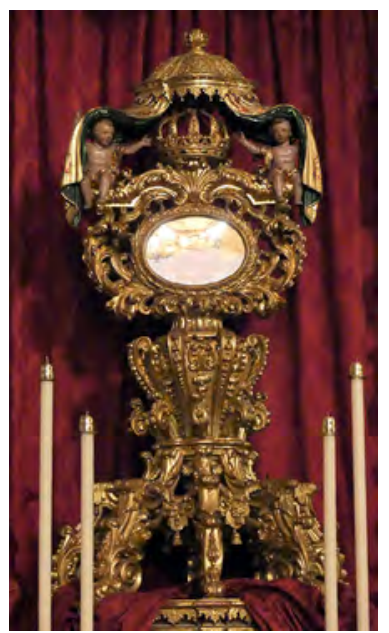

Foto 12. Andas-custodia del Corazón de Jesús.

Parroquia de Ntra. Sra. de la Concepción. La Orotava.

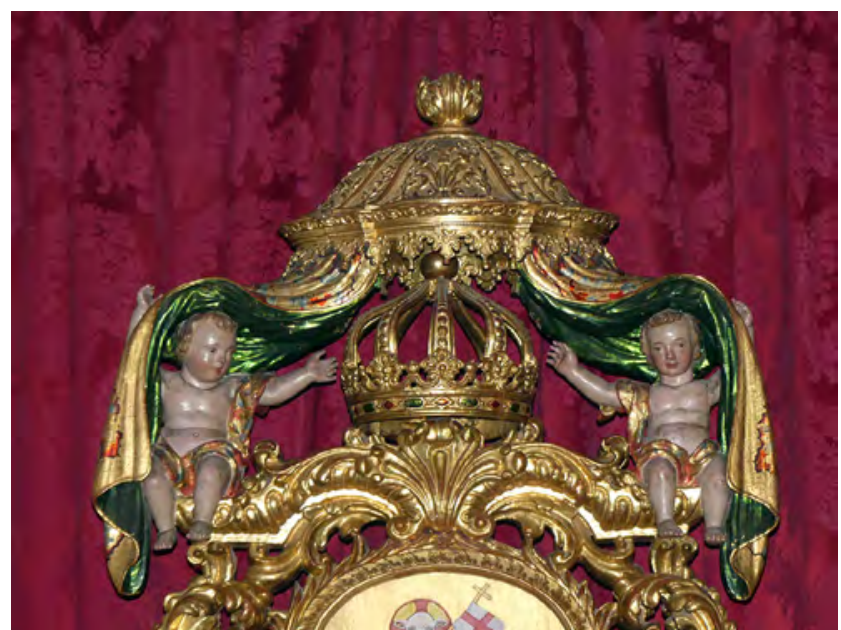

Foto 13. Detalle. Andas-custodia del Corazón de Jesús. Parroquia de Ntra. Sra. de la Concepción. La Orotava.

poder contemplarlo y fotografiarlo, frontalmente, me percaté de las muchas coincidencias con las labores de Beraud, que tras la lectura de su testamento se corroboraron. La obra presenta recursos del maestro en los diseños, la compositiva y la resolución en la talla. De igual manera la presencia de los ángeles que abren el pabellón, ambos recursos compositivos del autor. El remate de la misma es un elemento clave para su confirmación y relación con otra obra desaparecida en 1978. El pabellón que remata las andas es una versión más pequeńa del que cerraba la urna del Santo Entierro de la parroquial del Realejo Bajo, al igual que la solución dada para los ocho pilares que sostienen la pilastra de la obra para las claras. Amplias volutas presentes en otros retablos salidos de su mano como el de Valois. Tanto el relicario como la Urna del Santo Entierro están relacionados con la familia Peraza de Ayala, como veremos más adelante (fotos 12 y 13).

La devoción al Corazón de Jesús floreció de manos de los hijos de san Ignacio de Loyola a lo largo del s. XviII en las Islas. En el valle de La Orotava tuvo dos claros ejemplos, el patrocinado por Isabel de Mesa para el convento de San José y el ubicado en el retablo de Cristo Preso de la parroquial del Realejo Bajo de manos de la familia Oramas. La devoción en el setecientos no se entendía, como sucede desde finales del s. XIx, asociada a una figura de Cristo que abre sus vestiduras para dejar ver el resplandeciente órgano vital. Por contra, en estas primeras representaciones se centran en el Sagrado Corazón, llameante, resplandeciente, cercado por la corona de espinas, la herida en el costado derecho y, en algunos casos, otros elementos de la Pasión como lanza e hisopo que se sitúan a su espalda. Todo ello en medio de un rompimiento de gloria acompañado por ángeles o santos que suelen contemplar el misterio. Así lo encontramos en el pequeño grabado colocado en su ermita de Los 
Dolores de Palo Blanco, Los Realejos, por Agustín Fernández Estévez de Vasconcelos en $1759^{70}$. La imagen mariana reproduce la conservada en el Colegio Imperial de la Compañía de Jesús de Madrid, mira hacia lo alto, donde contempla la figuración del Corazón de Jesús, en medio de un rompimiento de gloria con la corona de espinas y a su espalda la lanza y el hisopo ${ }^{71}$. Rodeado de ángeles, rematado por la Santa Cruz que se introduce en la vena aorta, aparecía en la puerta del sagrario patrocinada por María Ascensión Oramas, esposa de Miguel Hernández Abreu, para el banco del retablo del Cristo Preso desparecido en el incendio de 1978 en el Realejo Bajo. Aunque se instituye la función en su testamento de 1780, donde se declara Oramas como la promotora $^{72}$, el estudio de la pieza nos permite darla como obra del pintor José Tomás Pablo (Puerto de la Cruz + 1778), activo en el valle de Taoro. La clave de la hornacina del retablo de la Virgen de Gracia en la iglesia de San Agustín de Icod de los Vinos aparece rematada por una pequeña pintura del Sagrado Corazón, con un marco ricamente tallado. Sus características nos permiten suponer que fue sobrepuesto al conjunto. Catalogado como obra anónima, deja entrever su filiación a los pinceles de Cristóbal Afonso (1742-1797), muy activo en Icod de los Vinos en la segunda mitad del setecientos. En la capilla de la Soledad del exconvento franciscano de Santa Cruz de Tenerife, actual iglesia de San Francisco, se conserva otro ejemplo similar. Sobre la puerta del sagrario como parte de la orla que la circunda se encuentra un grabado coloreado como remate. Dos padres jesuitas contemplan un rompimiento de gloria donde el Sagrado Corazón, llameante y atravesado por la lanza de Longinos, aparece rodeado por la corona de espinas a modo de orla. El Sagrado Corazón en este caso vierte su gracia a los corazones terrenales. Sobre la representación se sitúan el Espíritu Santo y Dios Padre, en medio de la gloria celestial. Prefiguración de la Santísima Trinidad que dota de más importancia a la devoción. En el convento de monjas clarisas de La Laguna se conserva, entre las obras expuestas en su museo, un ostensorio que acoge a los corazones de Jesús y María, en medio de un rompimiento de celestial. Añade, como en el caso anterior, la prefiguración de la Santísimo Trinidad, obra anónima de mediados del s. XviII. Como vemos, son modelos similares en el siglo XviII, vinculados a la presencia de los jesuitas en la isla y en el valle de La Orotava (foto 14).

Así pues, el encargo que realizó la clarisa Isabel de Mesa al maestro Beraud debía contener una figuración similar del Corazón de Jesús. Bien con un grabado o por el fondo dado al viril de la pieza para un medio o alto relieve. Las andas procesionales encargadas por la religiosa, no solo tenían una función procesional, sino cultual, pues formaban parte de un altar en la iglesia del convento de San José. Tras la expulsión de los jesuitas de los reinos hispanos en 1767 estas versiones y cultos fueron decayendo o incluso retirados. Así sucedió con el caso estudiado, donde la

70 Camacho y Pérez-Galdós, Guillermo: opus, cit.

71 Grabado de pequeño tamaño que aparece enmarcado siguiendo los gustos presentes en la Isla, de cornisa con tallas en los ángulos y remata de formas vegetales de amplio desarrollo. Con la singularidad de ser repujado en plata, trabajo de plateros tinerfeños de mediados del setecientos.

72 Idem. p. 18. 


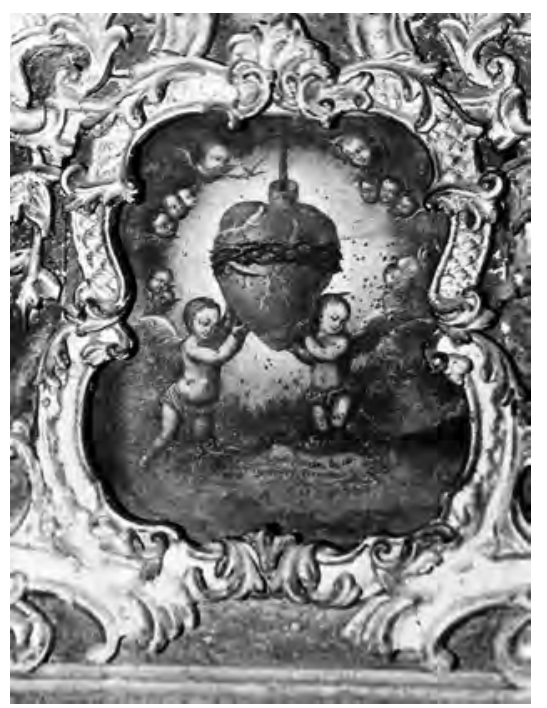

Foto 14. Sagrado Corazón de Jesús. Atribuido a José Tomás Pablo. Retablo del Señor Preso. Parroquia de Ntra. Sra. de la Concepción, Los Realejos. Desaparecido. Anónimo, s. xx. Col. particular.

composición fue retirada del culto por orden del comisario local del Santo Oficio en 1792. Como relata Juan Alejandro Lorenzo Lima en el templo de las franciscanas se celebraban "funciones en su honor "con sermón y todo aparato" coincidiendo con los cultos propios del viernes siguiente a la Octava del Corpus». La misma censura fue la causante de la retirada de otro lienzo, donde se figuraba a la sagrada imagen, en la iglesia de las monjas catalinas de la misma villa ${ }^{73}$. Con la prohibición de 1792 la obra de Beraud debió de permanecer entre los muros del convento de San José, retirado del culto, desde donde fue trasladado a las dependencias parroquiales de la Concepción. El corto tiempo de uso asociado al culto primigenio, junto a la desamortización y los cambios sociales y cultuales que desde el s. XIX se vienen sucediendo, propiciaron la pérdida de la memoria de su concepción primigenia. En la actualidad aparece identificado como un relicario procesional, cuando como el mismo Guillermo Beraud la define en su testamento son «unas andas o custodia». De su donante, Isabel de Mesa, desconocemos el año de su fallecimiento, al igual que la de muchos otros religiosos. Hija de Francisco de Mesa Azoca y Mesa (La Laguna, 1658-1726) y María Mesa y Barbosa (1660-1741) era hermana de Juana de Mesa y Castilla, quien, en 1731, casó con el regidor Francisco Antonio Peraza de Ayala y Castilla-Herrera (Realejo Bajo, 1706-1782). La donante de las andas para el Corazón de Jesús era cuñada del prioste hereditario de la función del Santo Entie-

73 Lorenzo Lima, Juan Alejandro (2008): «Arte y religiosidad jesuítica en Canarias. Un ejemplo a través del colegio de San Luis Gonzaga, La Orotava», XVIII Coloquios de Historia Canarias-América, Las Palmas de Gran Canaria. 
rro del Realejo Bajo. Lo que motivaría del encargo a Guillermo Beraud de las andas del Sagrado Corazón que tantos elementos comparte con la urna del Santo Entierro desaparecida en el incendio de la parroquial realejera en 1978. Los soportes de las andas, con esas amplias volutas, el asiento para los ángeles, ahora desaparecidos, y el pabellón que lo remata son idénticos a los mismos elementos que conformaban las andas del Viernes Santo realejero. La base de la misma tallada en finos tallos y cuentas, rematadas con una rica guardamalleta, y recortadas cornisas, son soluciones similares a la peana central del retablo de santa Bárbara Mártir. Solución similar a la guardamalleta que remata el interior del sagrario del retablo de la Misericordia en la misma parroquial del Realejo Alto. Las andas de La Orotava y Los Realejos aparecen cubiertas por desarrollados pabellones nervados, con ricas tallas que imitan tejidos labrados. Las similitudes entre ambas piezas son tan evidentes como que el remate de las andas villeras son una réplica del pabellón de la Urna del Realejo Bajo. Pabellón nervado y cortinaje abierto por ángeles, que aparece de igual manera resuelto en el retablo del Tránsito del convento lagunero. Los ángeles que abren el viril al público son otro ejemplo postrero de las capacidades como escultor del maestro Beraud.

Los Peraza de Ayala eran un linaje que al menos desde el siglo Xvir disfrutaban de una posición económica holgada en la sociedad tinerfeña. En Los Realejos entroncaron con los Oramas, promotores de la parroquia de La Concepción y poseedores del patronato de la capilla de la Candelaria, cabecera de la nave del Evangelio. El capitán Juan Díaz Oramas, familiar del Santo Oficio, logró en 1665 el patronato de la función del Santo Entierro, para el que compró las imágenes y enceres necesarios. Las mismas salían cada Viernes Santo desde su casa, donde se encontraban durante el resto del año, hacia la parroquia para protagonizar los cultos propios del día. Un alto grado de distinción social, poco habitual, que contó con ejemplos similares en Garachico, donde perdura de manera inversa, y San Juan de la Rambla, que sobrevivió hasta el siglo xx. Sus antepasados agregaron otras fundaciones como la dedicada a san José y los cultos propios de la capilla, lugar de su enterramiento. Como refleja el documento fundacional, los Díaz Oramas mandaron hacer las imágenes necesarias para la procesión de la tarde del Viernes Santo ${ }^{74}$. La transmisión hereditaria hace que todas las obligaciones y honores pasaran en manos de los Peraza de Ayala en cuyos hermanos Francisco Antonio y Baltasar Gabriel, sus nietos, encontraron renovación y continuación. Ellos escribieron uno de los capítulos más destacados para la familia en el siglo XviII. Tras el obligado reparto de los diversos mayorazgos que concurrían en sus manos, los hermanos decidieron renovar la capilla de la que eran patronos en la parroquial de Realejo Bajo. La misma había sido ampliada, en altura, durante las últimas obras que habían afectado al edificio parroquial en el tránsito de siglo, correspondiéndole a la familia el ornato interior. Su abuelo, el capitán Juan Díaz, había contribuido con 1000 ducados y su padre Francisco Peraza con 100 al igual que otros familiares a la fábrica parro-

\footnotetext{
${ }^{74}$ Mesa Martín, José María: opus. cit., s/f.
} 
quial. La intervención de los hermanos aparece citada, aún hoy, en la lápida que cierra el paso a su sepulcro bóveda, donde reza la iniciativa de la misma de manos de Baltasar Gabriel en 1738. Otras obras de mejora que debieron ser realizadas por su hermano Francisco Antonio, del que el nobiliario de Canarias, al citarlo como patrono de la misma capilla, dice de él «en cuyo recinto hizo importantes mejoras y donde fue prioste de de las funciones de San José y del Santo Entierro, a imitación de sus mayores" ${ }^{75}$. Así pues, se evidencia el vínculo que ambos hermanos tuvieron con la parroquia y cómo Francisco Antonio continuó una vez que su hermano se establece en La Laguna, donde construye la residencia y capilla de la Trinidad. Como deja ver el nobiliario, ejerció de prioste de la función del Santo Entierro y por esa misma condición y por ser de su propiedad los enseres (las imágenes como el Cristo Difunto, una Dolorosa, san Juan, Santos Varones y las ropas y parihuelas correspondientes), debió de contribuir con el aumento y conservación de los mismos. Elementos que se custodiaban en su vivienda o en la medianera de sus abuelos, que también le pertenecían. Obligaciones y mejoras en las que se incluyen la realización de unas nuevas andas para el Cristo, que estuviera a la altura de la posición de la familia, incrementada con ellos, pues ambos llegaron a ser regidores propietarios del Cabildo Insular. Los cargos militares complementaban el prestigio social, pues en sus manos estuvieron los mandos de la milicia de Los Realejos, Francisco Antonio fue capitán del regimiento desde $1742^{76}$. Esa imagen de posición y esplendor debió de materializarse en la adquisición de esas nuevas andas, renovadoras de lenguajes y diferenciadas del resto de las realizadas hasta ese momento en la Isla. El cargo militar que detentaba Francisco José Peraza le permitiría tener una relación más estrecha con Guillermo Beraud, que, además de afamado tallista, tenía el cargo de ayudante dentro de la milicia, como bien se refleja el testamento de su esposa. Eso, unido a la condición de vecinos del mismo casco, permitiría la facilidad de trato y la colaboración de Beraud en estas labores. La condición de bienes propios vinculados a su casa impide conocer, hasta el momento, detalladas cuentas de los trabajos, referencias a los mismos o demostrar la autoría de manera documental. De igual manera no se incluye entre los bienes vinculados a su persona en su testamento redactado en 1766. Casi veinte ańos después, en 1782, realiza un codicilo donde, lo poco que se lee en el mismo, dada la pérdida de tinta, no deja entrever mayor información al respecto. La urna del Santo Entierro fue la pieza más destacada de cuantas componían la Semana Santa del Realejo Bajo antes del incendio ${ }^{77}$.

75 Fernández de Bethencourt, Francisco (1959): Nobiliario de Canarias, tomo int, p. 216.

${ }^{76}$ Peraza de Ayala, José (1938-1939): «El linaje español más antiguo en Canarias», Revista de Historia de Canarias. Facultad de Filosofía y Letras, La Laguna.

${ }^{77}$ En la actualidad se ha realizado una réplica muy acertada, inacabada en las labores de dorado. La misma corresponde a la iniciativa de José Hernández Siverio y su esposa Inés Rodríguez Suárez, que con la ayuda del pueblo lograron la reconstrucción del mismo. Iniciativa tomada en recuerdo de la promesa realizada por su tío Constantino Siverio, para la conservación y atendimiento del paso tras la recuperación de una enfermedad. La pieza en estado de abandono, tras el paso de los años después de su entrega a la parroquia por la familia Peraza de Ayala, fue restaurada por su ini- 


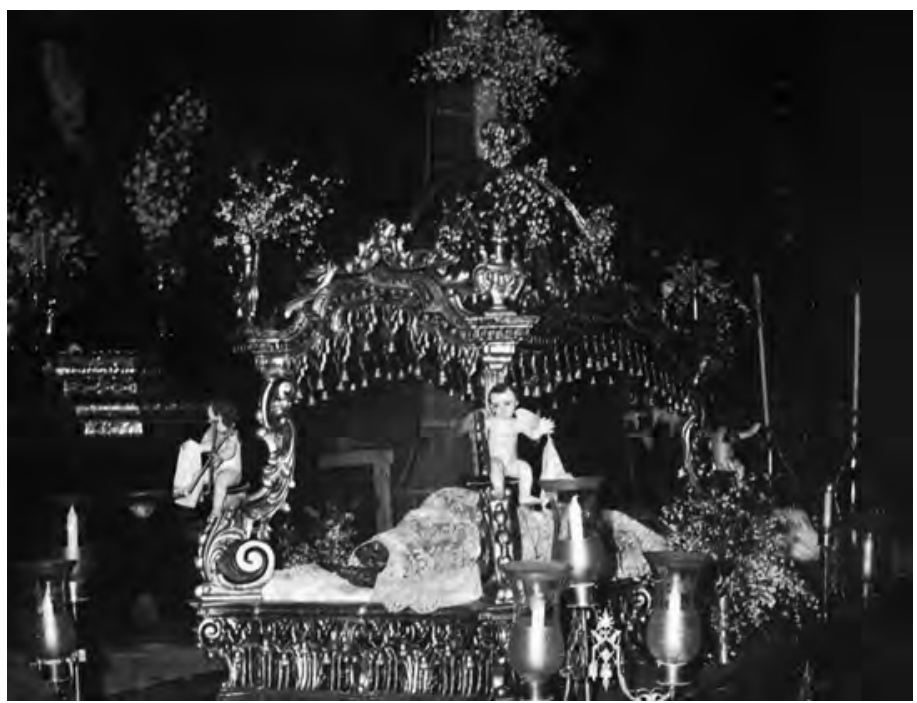

Foto 15. Urna del Santo Entierro. Parroquia de la Concepción, Los Realejos.

Desaparecida en el incedio de 1978. Col. particular. Los Realejos.

Se componía de un pabellón rectangular nervado dividido en ocho tramos, tallado en relieve en el exterior y bajorrelieve en su interior, rematado por un gran capullo floreciente, al igual que el caso orotavense. El pabellón se remataba en sus extremos inferiores por cartelas de tallos y rocallas encintados. Todo el remate se sostiene por cuatro pilares, de formas vegetales, que se apoyan sobre amplias volutas. Los pilares, al igual que sucede en el caso de las andas procesionales de La Orotava, sirven de asiento para cuatro angelotes portadores de las insignias de la Pasión ${ }^{78}$. La base de todo el conjunto moldurada y con pilares que resaltan los puntos de apoyo de las bases y el centro de sus lados, composición similar a la aplicada en la base de la imagen de santa Bárbara Mártir en la vecina parroquial de Santiago. En todo el conjunto está presente como remate una guardamalleta decorada por flores de bajorrelieve y borlas talladas, de igual manera que en las obras de su mano en el Realejo Alto y La Orotava. Todo el conjunto aparecía dorado y policromado, con corlas de tonos rojos, que realzaban la idea de plasticidad de los tejidos, propia del Barroco, a imitación de ricos tejidos labrados en hilos de oro y plata. Así pues, las andas del

ciativa. Primero el Cristo en los talleres de Nicolás Perdigón y ya en los años sesenta del siglo xx por Ezequiel de León, quien restauró las andas y recuperó el esplendor de los dorados y corlas. Todo el material fotográfico de este proceso permitió su recuperación en los años ochenta-noventa por parte del taller de José Navarro «el canario» y, posteriormente, las tallas de Pablo Martín Abrante, con diseño de las plantillas a cargo del Eleuterio Garrido Luceño.

${ }^{78}$ De todo el conjunto son las únicas piezas que han sobrevivido, pues en el momento del incendio y varias décadas antes se conservaban en manos de la familia de los mayordomos del paso. 
Cristo Yacente o Urna del Santo Entierro realejeras debemos encuadrarlas en los años cincuenta del setecientos, anteriores a la andas o custodia del Sagrado Corazón encargadas por Isabel de Mesa, última obra del maestro (foto 15).

A la muerte de Baltasar Gabriel Peraza de Ayala su cuantioso mayorazgo pasó a manos a de su hermano Francisco Antonio, concentrando en sus manos varios mayorazgos familiares. Su hermano menor había casado en dos ocasiones, la primera con Juana de Mesa y Castilla en mayo de 1731, con la que había tenido cinco hijos. La mayor superviviente era Francisca de Paula Peraza de Ayala y Mesa, que había contraído matrimonio con Pedro de Ponte y Benítez de Lugo, V conde del Palmar ${ }^{79}$. Tras la muerte de su primera esposa contrae nuevo matrimonio con María de la Encarnación Viña y Tenudo del Castillo en junio de 1745, su sobrina, con quien logra la sucesión masculina en Cayetano José Peraza de Ayala y Viña ${ }^{80}$. Centrándonos en el caso de la herencia y la posibilidad de disponer de ella, el poseer algunos de los mayorazgos familiares impedía el disfrute de otros, por lo cual, a la muerte de su hermano Baltasar Gabriel y asumir sus propiedades como su heredero Francisco Antonio, entraba en conflicto. Por esta razón, Francisca de Paula Peraza de Ayala, hija mayor del primer matrimonio, reclama para sí el mayorazgo de sus abuelos, los Díaz Oramas, y con ello los honores de la función del Santo Entierro. Es por ello que pasó de la Casa de Peraza a la de los condes del Palmar, que habitaron una de las casas de los Peraza al lado de la iglesia. Desde ella y como relata Guillermo Camacho: «De allí era traído el Viernes Santo para la procesión y ceremonia del Santo Entierro» ${ }^{81}$, privilegio que se mantuvo hasta el s. XIX en que fue entregada las andas y la imagen a la parroquia, hasta su desaparición en el incendio de 1978. Magníficas andas de pabellón que en su tiempo, tal vez por su condición privada, o estar oculta a la mirada diaria de un edificio parroquial, parece no tuvieron influencia en otras creaciones de similar uso. Lo contrario sucedió con el modelo creado para el Cristo Difunto del convento dominico de La Laguna, regalo del famoso Amaro Pargo en 1732. De las andas realejeras, tras el incendio, aún se conservan los cuatro ángeles portadores de las insignias de la Pasión que ya había atribuido a la mano de Beraud $^{82}$ (fotos 16 y 17).

Este estudio de la obra de Beraud no puede ser concluido sin incluir en la lista de obras asociadas a su mano las andas de baldaquino de la parroquia de San

${ }^{79}$ Como declara en su propio testamento, de su primer matrimonio corresponden: José Antonio Peraza de Ayala, Francisca de Paula, Ana María Peraza de Ayala y Mesa, esposa del sargento D. Fernando de Molina Machado y Castilla, regidor de la Isla, ya fallecida en 1766, y dos hermanas más, Paula de San José y María Antonia del Sacramento religiosas agustina descalzas del vecino convento de San Andrés y Santa Mónica, del que llegaron a ser abadesas.

${ }^{80}$ Del segundo matrimonio tuvo por hijos, según su testamento: Eustaquio Peraza de Ayala, Cayetano, Miguel, María de la Concepción, Alejandra y Juana Peraza de Ayala.

${ }^{81}$ Camacho y Pérez-Galdós, Guillermo: opus. cit.

82 Rodríguez Cabrera, Germán F. (2003): «Ángeles de Pasión», en Semana Santa. Los Realejos, Ayuntamiento de Los Realejos. A día de hoy, 2019, me causan dudas de su autoría en los ángeles pasionistas del paso de La Oración en el Huerto de la Orden Tercera de Santa Cruz de Tenerife, no me parecen de su mano. 


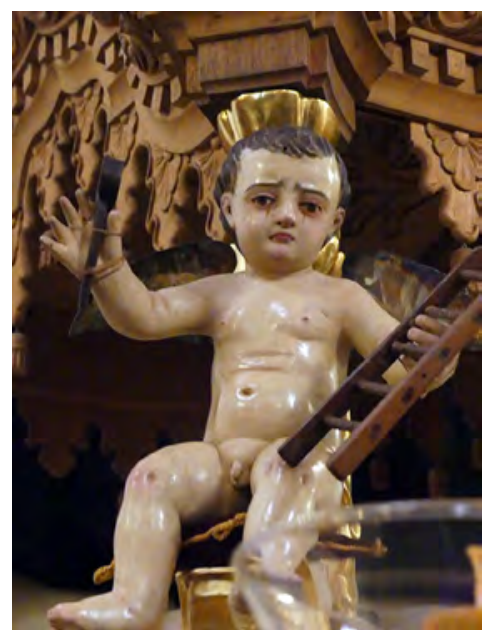

Foto 16. Ángel portador de las Armas Cristi. Parroquia de Ntra. Sra. de la Concepción. Los Realejos.

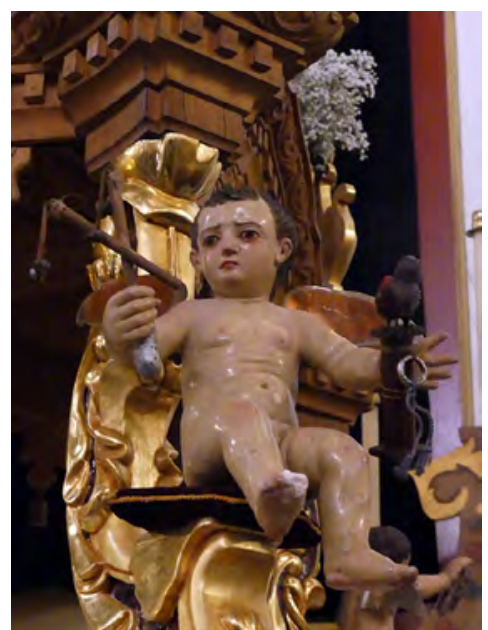

Foto 17. Ángel portador de las Armas Cristi. Parroquia de Ntra. Sra. de la Concepción. Los Realejos.

Marcos de Icod de los Vinos. Destinadas al culto de Nuestra Señora del Rosario, cuya cofradía se estable en la parroquia con anterioridad a 1668. Confraternidad que contó, como era usual en otras similares, con el apoyo de las principales familias del lugar. El estudio documental de la misma se hace difícil ante la escasez de noticias que aportan los fondos parroquiales. En marzo de 1855 el archivo parroquial recoge que no se sabe mucho de la Cofradía del Rosario de Nuestra Señora por

estar destrozado enteramente el libro de su institución y se infiere de documentos que obran en el mismo, que fue anterior al año 1668. Hay algunos hermanos que asisten a la función de la Virgen y los de Semana Santa... ${ }^{83}$.

de lo que se sobreentiende la poca actividad que poseía la misma a mediados del ochocientos y por otro lado, en unas fechas nada favorables para las asociaciones de fieles. La cofradía del Rosario de la parroquia matriz de Icod de los Vinos sí tenía actividad siglos antes y apoyos sociales suficientes. En el testamento del capitán Antonio Afonso Gallegos, de 1766, mayordomo de la ermita de Buen Paso, deja dos ducados a cada una de las hermandades de su pertenencia o devoción: la del Santísimo Sacramento, del Rosario, El Carmen y la de San Agustín ${ }^{84}$. Con este escaso pano-

${ }^{83}$ Archivo Parroquial de San Marcos de Icod de los Vinos (APSMI). Caja Documentos sueltos, «Papeles relativos a las Hermandades. 24 de marzo de 1855».

${ }^{84}$ Archivo Municipal de Garachico, (AMG) Fondo Casa de Cáceres, caja 21, doc. 23. En él documenta querer ser enterrado en las tumbas de Montiel, capilla de La Soledad, en el templo agustino de Icod, que era patronato de su primo. 


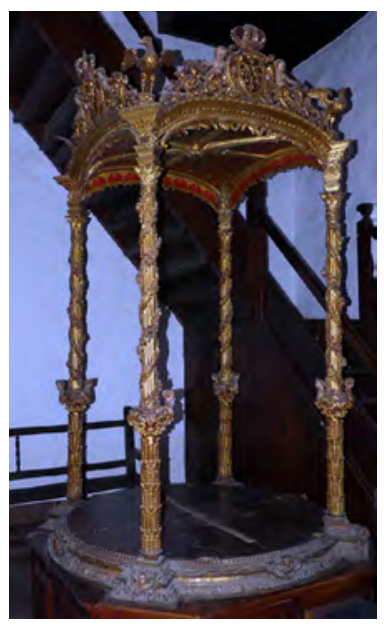

Foto 18. Andas de baldaquino de la Virgen del Rosario. Parroquia de San Marcos. Icod de los Vinos.

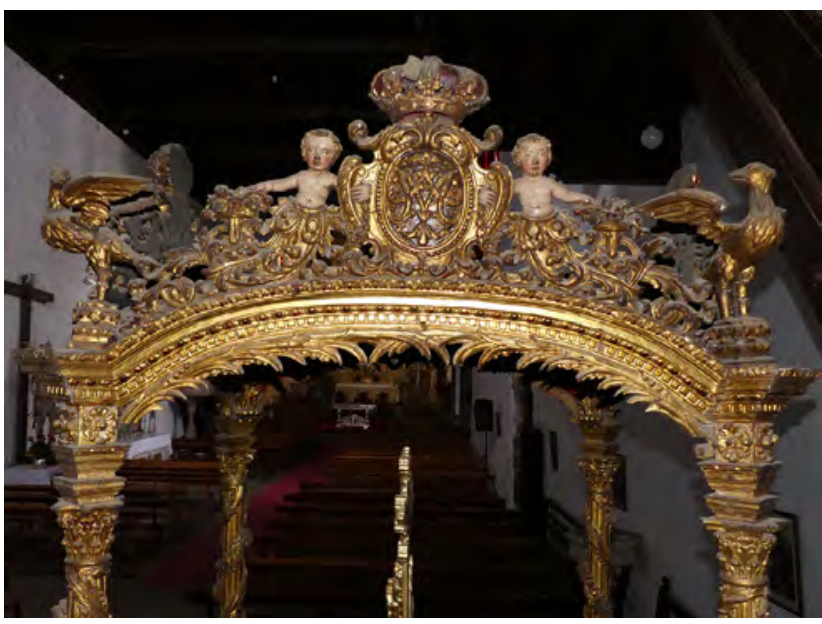

Foto 19. Detalle. Andas de baldaquino de la Virgen del Rosario. Parroquia de San Marcos. Icod de los Vinos.

rama documental el estudio de la obra es fundamental para la atribución a las gubias del maestro Guillermo Beraud. Tal vez por la escasez de fuentes o la rareza de las mismas, tampoco ha sido objeto de estudio para la historiografía insular. Tallada, dorada y policromada, se compone de cuatro columnas, que no pilares abalaustrados, sobre base moldurada con una cabeza alada tallada en cada uno de los arranques. Las columnas siguen el orden compuesto, con fuste acanalado, con su primer tercio cubierto de tallos vegetales que rematan una guirnalda que sostenida por cuatro angelitos que se mezclan con ella. La guirnalda que baja desde la base del capitel con profusión de flores, hojas y frutos es un alarde técnico similar a las tallas presentes en el retablo de santa Bárbara Mártir. Las andas se cubren por una bóveda nervada, sin talla en sus planos, rematada a modo de clave por una perillón o copa. Los frentes superiores del mismo se abren por medio de palmas entrecruzadas. La parte alta de las andas se rematan, tras las palmas y las líneas de cornisas, poco desarrolladas, por amplias cartelas. Desarrolladas como soporte de un blasón mariano que los centra, rodeado por el Rosario y rematado por una corona imperial, similar a la usada en las andas -custodia del Corazón de Jesús de La Orotava-. Sosteniendo el emblema mariano de cada una de las cartelas, dos ángeles que las enlazan con la decoración vegetal de la misma. Como remate en cada uno de sus extremos, cuatro águilas con las alas desplegadas, igualmente talladas y doradas. El baldaquino no 
posee sol de flameantes rayos, similares a las características de la obra ${ }^{85}$. La singularidad de las mismas, la rareza de ser doradas y talladas (frente a las más generalizadas forradas de planchas de plata repujada), sus ricas labores de gubia hacen de las andas del Rosario una pieza verdaderamente única en el panorama insular. Características que son comunes con otras obras del maestro Beraud, lo que me hace atribuirlas a su mano (fotos 18 y 19).

Las apariciones de nuevas fuentes documentales aportarán más información sobre los encargos, los comitentes, las condiciones de trabajo o el lugar donde se accidentó y cercenó una estancia tan productiva de las Islas. El impacto de su producción en Tenerife está por calibrar en su totalidad, pero los cambios de gusto, las modas y las crisis económicas que afectaron a la Isla evitaron el desarrollo de programas tan elaborados en talla. Las nuevas creaciones, ya avanzada la segunda mitad del setecientos, derivan a formas más simples, retablos de maderas recortadas y estípites lisos, de andas forradas en planchas de plata o cubiertas de pan de plata. Poner en valor y estudio elementos como las andas procesionales, del que poco se ha trabajado hasta el momento en las Islas, ayudará a conocer más sobre su figura e influencia. Todo ello ante una realidad, la del patrimonio religioso, que no siempre ha dado buenos ejemplos de conservación y puesta en valor de este tipo de elementos. Así pues, espero que el presente trabajo contribuya a profundizar sobre este campo y la figura, vida y obra de un maestro francés que llegó a las costas de Nivaria en la primera mitad del s. XviII.

Recibido: 01-04-2019. Aceptado: 11-04-2019

${ }^{85}$ El que se asocia a la pieza es una obra exenta de ráfagas, en plata labrada, completado por doce estrellas, fue regalo de presbítero Marcos Francisco Bello en torno a 1772. En la actualidad es usado igualmente como pieza exenta por la Virgen de Gracia y la Dolorosa. Martínez DE LA PeÑa, Domingo (2001): La Iglesia de San Marcos Evangelista de Icod y la vida del Siervo de Dios Fray Juan de Jesús, Ayuntamiento de Icod de los Vinos. 